\title{
Impacts of Cruise-Ship Entry Quotas on Visibility and Air Quality in Glacier Bay
}

\author{
Nicole Mölders ${ }^{1 *}$, Scott Gende ${ }^{2}$ \\ ${ }^{1}$ Department of Atmospheric Sciences, Geophysical Institute and College of Natural Science and Mathematics, \\ University of Alaska Fairbanks, Fairbanks, AK, USA \\ ${ }^{2}$ Glacier Bay Field Station, National Park Service, Juneau, AK, USA \\ Email: *cmoelders@alaska.edu
}

Received 24 September 2015; accepted 10 November 2015; published 13 November 2015

Copyright (C) 2015 by authors and Scientific Research Publishing Inc.

This work is licensed under the Creative Commons Attribution International License (CC BY). http://creativecommons.org/licenses/by/4.0/

(c) (;) Open Access

\section{Abstract}

Managers at Glacier Bay National Park must annually determine the allowable number of cruiseship entries into the park. This decision considers how differences in visitor volume may affect park resources. This study quantified the impacts to air quality and visibility under different ship quotas using simulations with the Weather Research and Forecasting model inline coupled with chemistry. Results of the simulation assuming two entries per day for May 15 to September 15, 2008 (QTA; 248 ship entries representing a 35\% increase) were compared to those of the 2008 cruise-ship activity (REF; 184) during that timeframe. A simulation without anthropogenic emissions (CLN) served to assess the overall impacts of cruise-ship emissions on visibility and air quality in Glacier Bay. Compared to REF, the increased entry quotas shifted chemical regimes and aerosol composition, depending upon thermodynamical conditions, and ambient concentrations. On days with notable regime shifts, sulfur-dioxide concentrations deceased while ammoniumsulfate aerosol concentrations increased. The increased quotas also altered the fine-to-coarse aerosol ratios in both directions despite constant ratio of fine-to-coarse aerosol emissions. In Glacier Bay, the days with worst visibility coincided with high relative humidity, although this relationship varied by scenario. On the $20 \%$ worst days, mean visibility was slightly better in CLN (mean haze index over Glacier Bay waters $\overline{H I}=2.9 \mathrm{dv}$ ) than in $\operatorname{REF}(\overline{H I}=3.1 \mathrm{dv}$ ). While increased emissions in QTA reduced mean visibility by $0.1 \mathrm{dv}$, the $10^{\text {th }}, 50^{\text {th }}$ and $90^{\text {th }}$ percentile of haze indices remained identical to those in REF. Best (worst) visibility occurred on the same days in REF and QTA due to emission impacts, but on different days than in CLN because relative humidity solely governed visibility in CLN. While calm wind played no role for visibility in CLN, wind speed gained similar importance for visibility as relative humidity in REF and QTA. Overall, increasing ship quotas would only marginally affect air quality and visibility as compared to REF, although even small changes in these parameters need careful consideration in the context of conserving the values of Glacier Bay.

*Corresponding author. 


\title{
Keywords
}

\author{
Glacier Bay National Park, Visibility, Air Quality, WRF/Chem, Cruise-Ship Emission Impacts in \\ Pristine Areas
}

\section{Introduction}

The demand for glacier viewing is likely to increase as "last chance" tourism highlights the need to see sensitive places before they disappear [1]. Glacier Bay National Park is a coveted destination to view a number of active tidewater glaciers and thus receives high demand for access. The National Park Service (NPS) has a mandate to both conserve park resources while also providing for appropriate opportunities for visitation. Specifically, the NPS manages parks to "...preserve unimpaired the natural and cultural resources and values of the national park system for the enjoyment, education, and inspiration of this and future generations" [2]. The NPS thus regulates the volume of visitation in the context of both access and impacts.

In 2015, over 95\% of all visitors to Glacier Bay arrived aboard cruise ships. Thus, a recurring issue for the park's superintendent is to decide how many cruise ships should be allowed in the park. Increases in cruise ships equate to more opportunities for enjoying park resources but also mean elevated emissions, which affect both air quality and visibility.

For example, cruise-ships emit sulfur dioxide $\left(\mathrm{SO}_{2}\right)$, nitrogen oxides $\left(\mathrm{NO}_{\mathrm{x}}=\mathrm{NO}_{2}+\mathrm{NO}\right.$, nitric dioxide, nitrogen-dioxide nitric oxide), and non-methane volatile organic compounds (VOC) as well as particulate matter (primary aerosols, e.g. sulfate, nitrate, organic carbon, elemental carbon) [3] [4]. The precursor gases may oxidize to form further gaseous pollutants as well as sulfate $\left(\mathrm{SO}_{4}\right)$, and nitrate $\left(\mathrm{NO}_{3}\right)$ [5]-[7]. In remote areas like Glacier Bay, cruise-ship emissions may be a major and perhaps only anthropogenic emission source [8].

Cruise-ship emissions are also of concern for visibility, and by extension impacts to visitor experience. Emission-related primary and secondary aerosols can affect the radiation budget in various and counteracting ways [9]. For example, aerosols absorb solar radiation. The high albedo of the glaciers enhances actinic fluxes with impacts on photochemistry. Aerosol deposition on glaciers decreases their surface albedo. Aerosols increase long-wave emissivity of liquid water clouds. Most water clouds contain enough water to behave like blackbodies in this spectrum range [9]. At high relative humidity, hydrophilic aerosols take up water vapor and swell to haze aerosols that act as efficient scatterers of solar radiation [10].

Haze makes the pollutants from cruise-ship emissions visibile to visitors. In Glacier Bay, pollutants and haze attributed to cruise ships may accumulate under frequently occuring inversions [11] affecting visibility [12]. Reduced visibility from haze runs counter to the values of the pristine air-quality standards in national parks (cf. [2]).

Aerosols also affect the irradiance via altered cloud microphysical processes. Enhanced aerosol concentrations due to ship-emissions increase the number of cloud droplets while decreasing their size [5]. Decreased cloud-droplet sizes increase cloud albedo and cloud lifetime [13]. Remote areas such as Glacier Bay are particularly sensitive to indirect aerosol effects due to low natural aerosol concentrations.

There are also consequences of emissions for aqueous chemistry and deposition. Small droplets are more acidic than large droplets [14]. Thus, the altered cloud microphysical processes and increased emissions may affect wet and dry deposition [15]. Both mean burden to ecosystems.

Since Glacier Bay is only accessible by water, and off the power grid, establishing and maintaining a monitoring network for air-quality is challenging. In winter, snow cover may make solar panels useless for power production. The typically calm wind conditions [16] exclude wind as an energy source. Both wind and solar energy also would need a backup power in form of batteries. Batteries may freeze during the harsh winter conditions. Generators are unsuitable, as their emissions could affect the visibility and air-quality measurements. Sites would have to be installed away from the bay's shores to not impair the visitor experience. The complex terrain also makes maintenance time consuming and expensive.

While few air-quality measurements exist for Glacier Bay, an air-quality modeling study focusing on conditions during the 2008 tourist season when 225 cruise ships entered Glacier Bay revealed that cruise-ship activity did not significantly impact air quality with respect to trace-gas concentrations and/or particulate matter [11]. 
The study also revealed that during certain synoptic conditions, pollutants from emissions in Icy Strait and/or in the Gulf of Alaska were advected into Glacier Bay [11]. However, on a few days under strong inversions, some of the cruise-ship-emitted pollutants persisted in the fjords for hours, raising the haze index, i.e. reducing visibility [12] and thus likely affecting visitor experience.

Currently, the NPS limits cruise-ship entries in Glacier Bay using both a daily (maximum = 2) and seasonal basis quota. For the seasonal quota, the 153-day season is divided into a 92-day "peak season" (1 June - 31 August) and a 61-day "shoulder" season (May, September). In 2008, the "peak" seasonal quota was set at 153 ships [17]. The shoulder season quota was set at 122 ships, although only 72 ships entered as weather limits the cruise demand during these months. Thus, the park could increase the seasonal quotas thereby allowing the maximum of two ships to enter every day. The superintendent of Glacier Bay must make this decision regarding the seasonal number of cruise ships allowed into the park on an annual basis.

The goal of our study is to examine the impacts of increasing the quotas to two entries per day over the tourist season. While the actual tourist season spans 1 May to 30 September, market conditions have resulted in a consistent lack of demand to meet the 122 entries shoulder-season quota. Thus, we defined the tourist season as 15 May to 15 September assuming the "peak season" quota is increased and realized at 184 ships (2 ships per day from 1 June - 31 August) and market conditions during the periods 15 - 31 May, and 1 - 15 September resulted in 2 ships entering the park per day.

Due to the lack of observations in Glacier Bay, no baselines of current or past pollutant concentrations and/or visibility conditions exist for the length of a tourist season or beyond. Therefore, a hierachy of air-quality simulations served to identify potential impacts of increased quotas on pollutant concentrations and visibility. As the quota for cruise ships has not changed since 2008, we used the pollutant concentrations in Glacier Bay in response to the 2008 cruise-ship activity as reference (REF) based on which we assess the impacts on air quality and visibility in response to increased quota (QTA). A simulation without any cruise-ship emissions (CLN) permitted to assess the deviation from an undistrubed atmospheric composition in Southeast Alaska including Glacier Bay.

\section{Experimental Design}

\subsection{WRF/Chem Setup}

The Weather Research and Forecasting model [18] inline coupled with chemistry (WRF/Chem) [19] was used in the setup of [12], [20], [11]. A further-developed Grell-Dévényi cumulus-ensemble scheme [21] and the WRFSingle-Moment 5-class scheme [22] determined cloud processes on the cumulus and resolvable scale, respectively. Shortwave and long-wave radiation processes were accounted for by the Goddard two-stream multi-band scheme [23] and Rapid Radiative Transfer Model [24], respectively. Aerosol-radiation and cloud-radiation feedbacks followed [25]. Surface and atmospheric boundary layer (ABL) processes followed [26]. The exchange of heat and matter at the atmosphere-surface interface was calculated by the modified NOAH land-surface scheme [27], [18], which also predicted soil-moisture and temperature, frozen ground and snow conditions.

The chemical mechanism [28] used inline-calculated photolysis rates [29]. Dry deposition of gases was calculated following [30] with the modifications for Alaska by [31]. The Modal Aerosol Dynamics Model for Europe [32] and Secondary Organic Aerosol Model [33] considered aerosol chemistry, dynamics and physics, some aqueous phase reactions, and aerosol removal.

\subsection{Emissions}

In all simulations, biogenic emissions were determined inline based on the meteorological and soil conditions following [34] [35]. Furthermore, WRF/Chem considered sea-salt uptake. This means all simulations consider these natural emissions.

In 2008, 153 cruise ships entered Glacier Bay during the 92-day peak season (1 June - 31 August) and 184 in total between May 15 and September 15. This timeframe is hereafter referred to as the tourist season or season. The reference simulation (REF) utilized this timeframe in 2008 to make inferences on activity-based emissions [12].

The 2008 activity-based ship emissions were calculated based on each cruise ship's characteristics (number and type of engines, engine power, maximum speed, fuel-type used, capacity) and the 2008 actual voyage data 
(ship position, cruise speed, operation mode) [12]. Hourly emission rates were determined for $\mathrm{NO}_{\mathrm{x}}, \mathrm{SO}_{2}, \mathrm{VOC}$, carbon monoxide (CO), ammonia $\left(\mathrm{NH}_{3}\right)$, and particulate matter (PM). VOC and PM-emission rates represented bulk-emission rates of several different species. PM was split into particulate matter of less than $2.5 \mu \mathrm{m}\left(\mathrm{PM}_{2.5}\right)$ and $10 \mu \mathrm{m}\left(\mathrm{PM}_{10}\right)$ in aerodynamic diameter at a 9:1 ratio following [3]. Furthermore, $\mathrm{PM}_{2.5}$ was split into unspecified $\mathrm{PM}_{2.5}$, sulfate, nitrate, organic matter, and black carbon following [3] [36]. VOCs were split into hexane, ethylene, propylene, acetylene, benzene, toluene, xylene, and others following [3].

The emission inventory for increased quotas encompassed the activity-based emissions of 2008 [12] plus the emissions due to additional cruises. The simulation using this emission inventory and its results is hereafter referred to as QTA. As we realistically assumed that the "peak season" quota would be met should the NPS increase it from 153 to 184 (two ships per day), we also assumed in accord with [1] that demand would result in two ships per day during May and September. Thus, our QTA could be considered a "worst-case" scenario where 248 total ships enter the park, a 35\% increase from the same period in 2008.

For simplicity, we assumed that increases in ship entries reflected the fraction of the current fleet. In the following, we call the cruise-ships of the two major companies, which currently are allowed in Glacier Bay, group 1 and group 2, while we combined the cruise ships from all the other companies into a group referred to as group 3. Again, for simplicity, we applied the 2008 fractional share of entrances of $37 \%$, $50 \%$, and $13 \%$ for the additional cruise ships in these groups. Consequently, group 1, group 2, and group 3 had 24, 32, and 8 additional entrances, respectively.

The cruise-ship type with the most entrances in 2008 in each group was chosen as representative for the additional cruise ships of that group. The representative ships of the three groups had total auxilliary engine powers of $17,700,14,000,10,100 \mathrm{~kW}$ and total main engine powers of 40,000, 39,000, and 40,000 kW with maximum cruise speeds of $12.3,11.8$, and $12.9 \mathrm{~m} \cdot \mathrm{s}^{-1}$, respectively. In cruising mode, the auxiliary engine loads amount $50 \%$, 60\%, and 30\%, respectively. All additional ships used intermediate fuel oil (IFO380) or marine gas oil (MGO) for their main engines, and heavy fuel oil (HFO) or marine diesel oil (MDO) for their auxilliary engines.

The typical paths, which these three cruise ships traveled within Southeast Alaska on their way to, in and from Glacier Bay in 2008 served as routes of the additional cruises. This means additional emissions not only occurred in Glacier Bay, but also in Southeast Alaska along the routes outbound to, and inbound from Glacier Bay. Since ship emissions not only depend on the ship's characteristics, but also on cruise speed, operation mode, and engine load, activity-based emissions were calculated assuming a typical cruising behavior for the additional ships (Figure 1). Like for the 2008 activity-based emissions, the emissions of particulate matter and precursor gases for the additional ships were calculated in dependence of the ships' individual characteristics and voyage data following [37].

The days with only one or with no cruise-ship entrance in 2008 were assigned to the three groups under consideration of the aforementioned share. To implement the quota of two entrances in Glacier Bay per day on all days, six additional ships were needed as they have to cruise to, in and from Glacier Bay (Figure 1). The designed cruise-schedules ensured entrance of Glacier Bay on the assigned days. To realize the above share and quotas, each of the three groups was assigned two additional cruise ships. Depending on their assigned cruise paths, the additional ships cruised three to five days within the area covered by the model domain. Consequently, the realization of the in total 64 additional entrances into Glacier Bay during the season resulted occassionally in up to six additional ships cruising Southeast Alaska per day.

\subsection{Simulations}

The WRF/Chem domain was the same as used by [20]. It encompassed the atmosphere over the eastern Gulf of Alaska, Southeast Alaska and western Canada centered at 58.5 N, $135.5 \mathrm{~W}$ with a $7 \mathrm{~km}$ increment of $120 \times 120$ grid-points and 28 vertically stretched layers to $100 \mathrm{hPa}$. To exclude lateral boundary effects from the analysis we discarded the five outermost grid-points leaving $110 \times 110$ grid-points for analysis (Figure 2). Doing so is common in limited area modeling [20].

Three simulations were performed for 15 May 2008 to 15 September 2008 with identical model setup except for the cruise-ship emissions. One simulation did not consider emissions from cruise-ships. It only considered the natural emissions. This simulation is called CLN as it represents a clean atmosphere. It serves to provide context to understand the overall impacts of cruise-ship emissions on air quality and visibility. Note that the other two simulations considered biogenic emissions as well. 


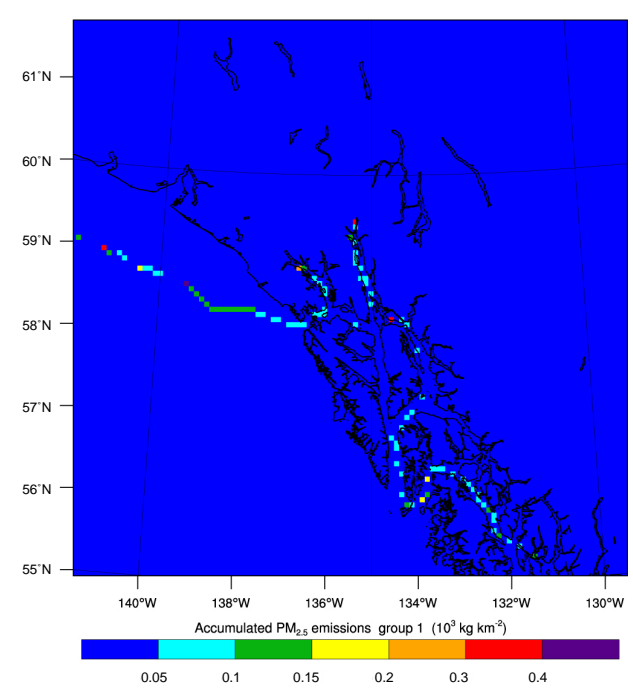

(a)

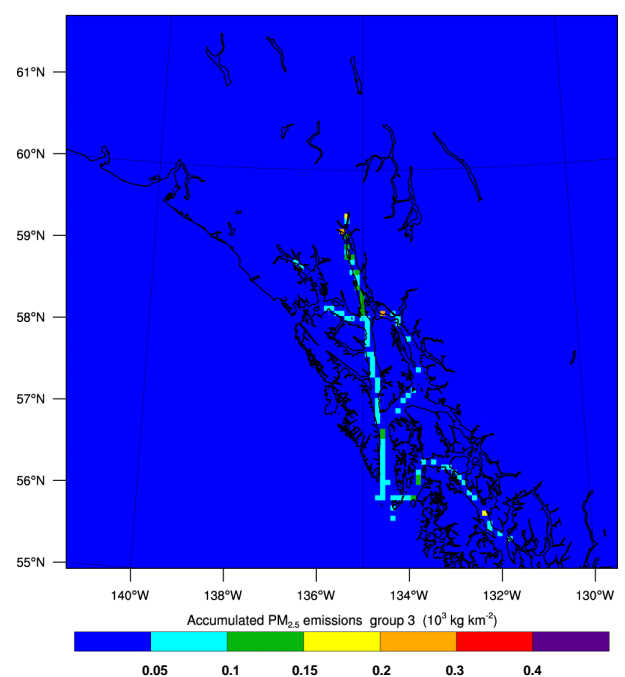

(c)

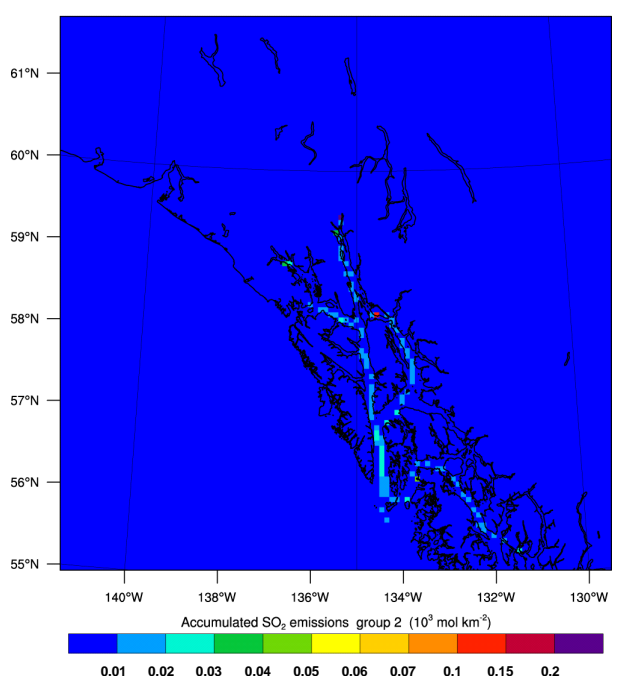

(e)

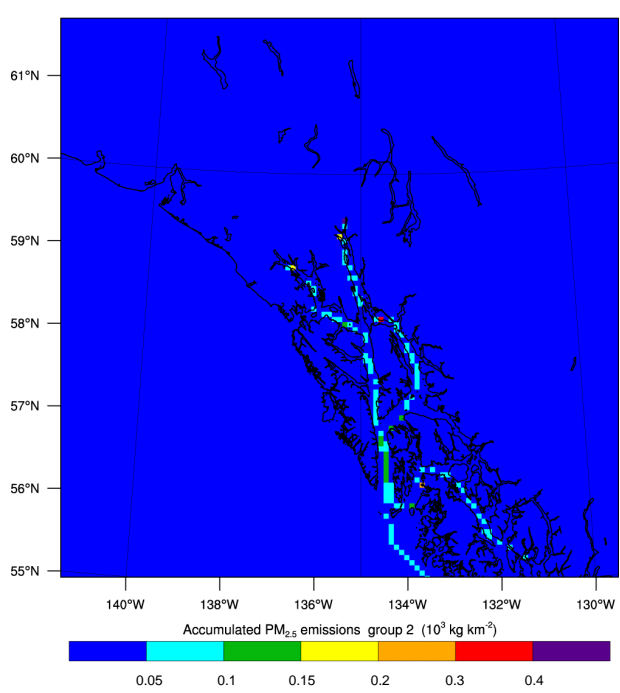

(b)

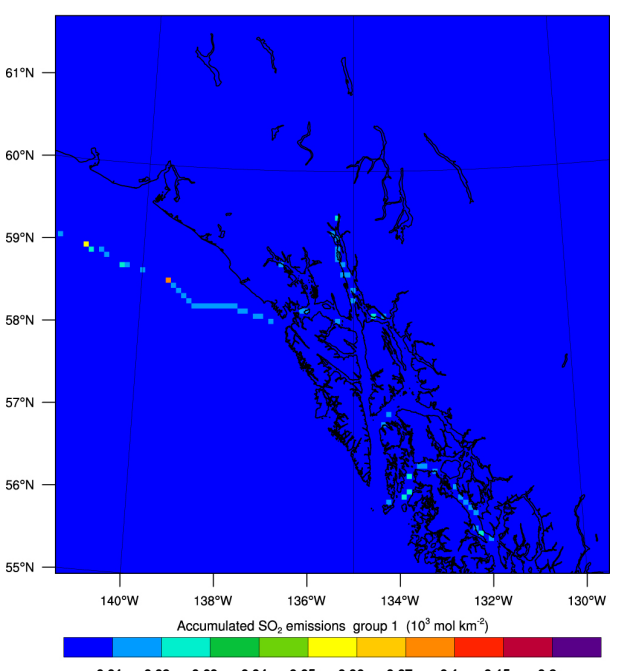

(d)

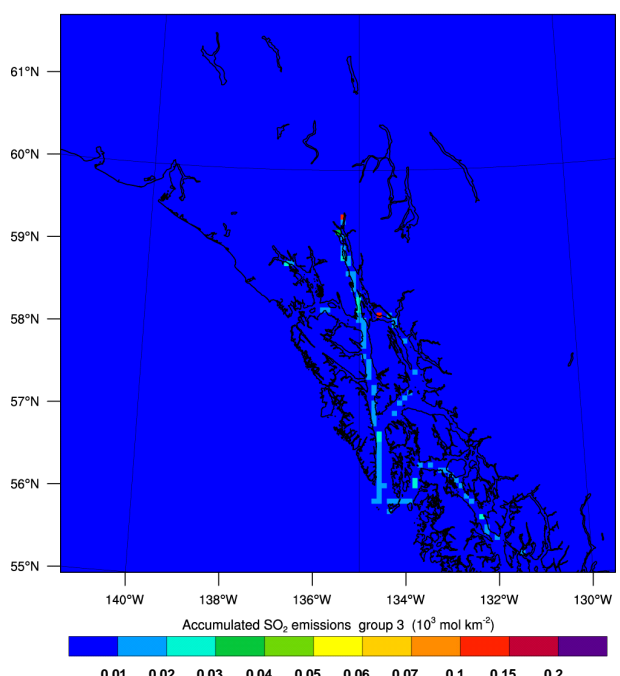

(f) 


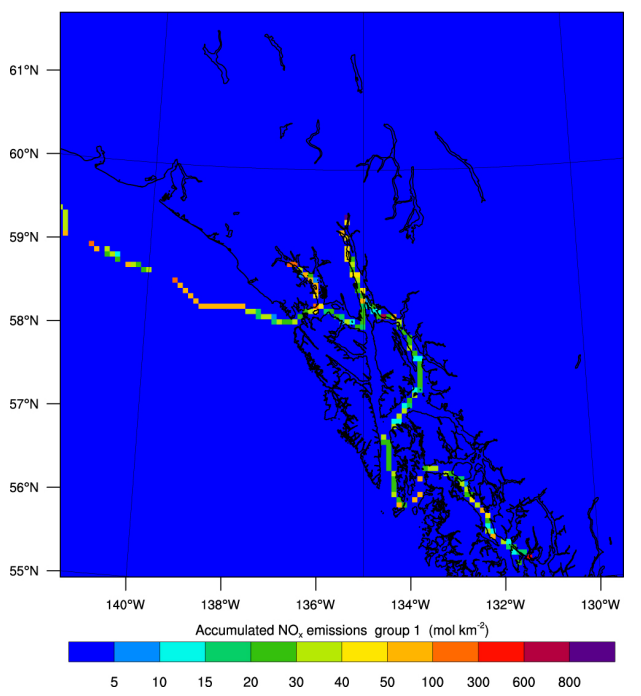

(g)

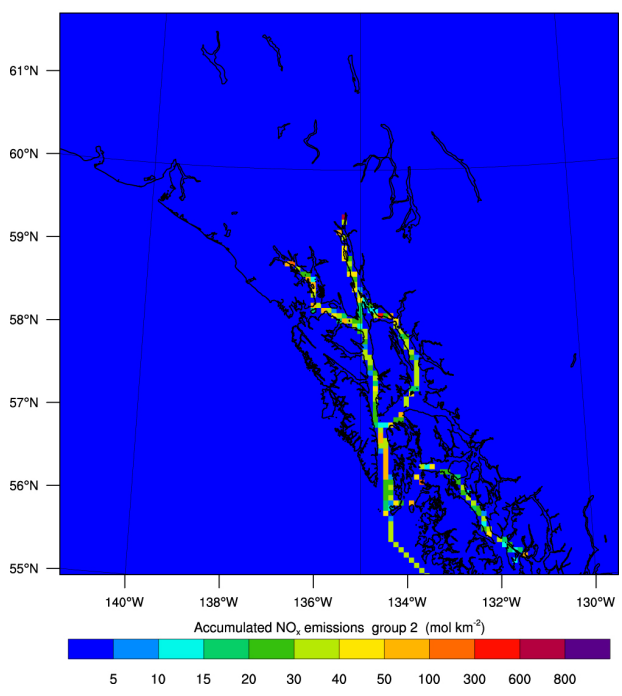

(h)

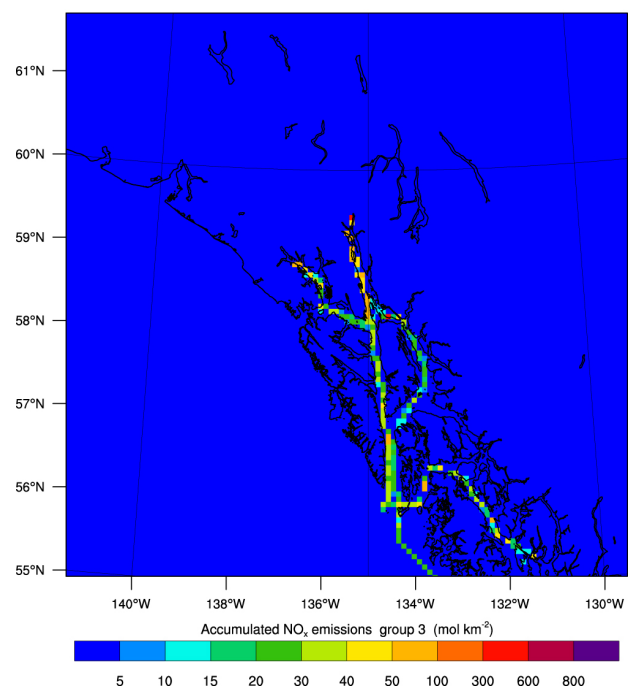

(i)

Figure 1. Comparison of mean accumulated ship emissions per voyage by the assumed three different types of additional ships of ((a), (d), (g)) group 1, ((b), (e), (i)) group 2, ((c), (f), (i)) group 3 for selected pollutants ((a)-(c)) $\mathrm{PM}_{2.5}$, ((d)-(f)) $\mathrm{SO}_{2}$, and ((g)-(i)) $\mathrm{NO}_{\mathrm{x}}$. Due to different berthing times at ports-of-call, cruise routes and speeds the voyages differ in duration among the three different types of additional ships assumed in this study. Note that the legend differs from that in Figure 2.

The reference simulation (REF) assumed the activity-based emission of 2008 [12] and is identical to the reference simulation in [12] [20]. For an evaluation of this simulation, see [11] [12].

The third simulation (QTA) assumed an increase in cruise-ship volume to two ships per day every day from 15 May - 15 September in Glacier Bay. The goal for this simulation was to compare visibility and air-quality conditions between the existing (REF) conditions and if the park decided to increase the ship-entry quota.

All simulations were initialized every five days with respect to meteorology using downscaled $1^{\circ} \times 1^{\circ}, 6 \mathrm{~h}$ resolution National Centers for Environmental Prediction global final analyses data [38] for sea-surface temperatures (SST), meteorological, snow and soil quantities. The meteorological data of these analyses also served as lateral boundary conditions for all three simulations.

All three simulations used identical idealized profiles of clean background concentrations for initialization. On all following days, the chemical fields at the end of the previous day served as initial conditions for the following 


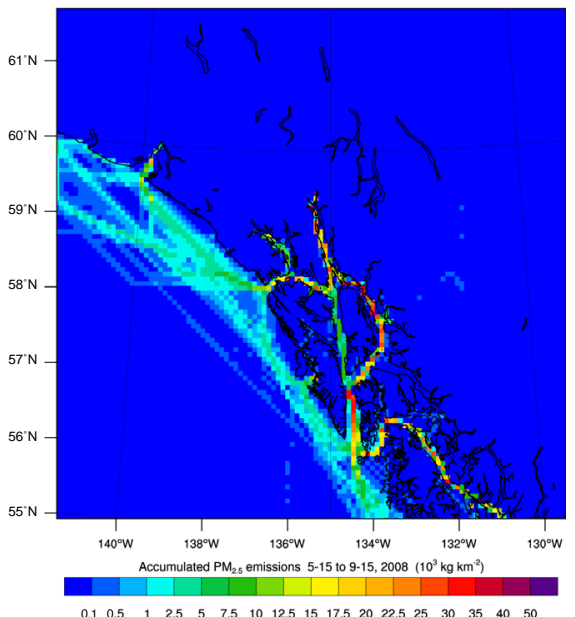

(a)

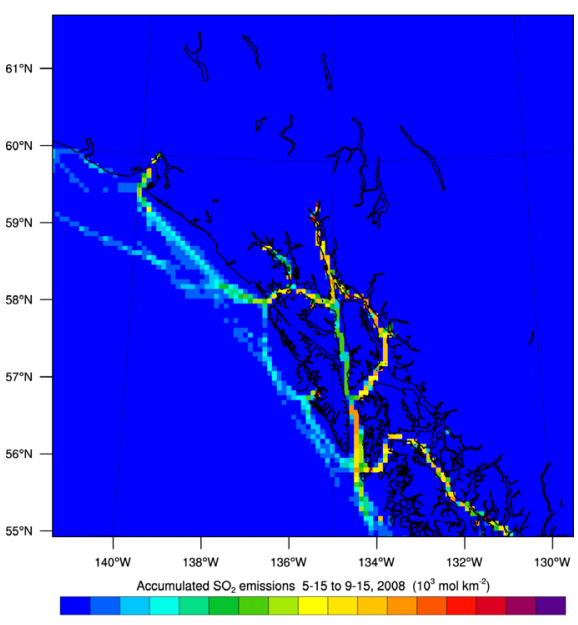

$0.25 \quad 0.50 .75 \quad 1 \quad 125 \quad 15 \quad 2 \quad 25 \quad 3 \quad 4 \quad 5 \quad 75 \quad 10 \quad 15 \quad 25 \quad 50$

(c)

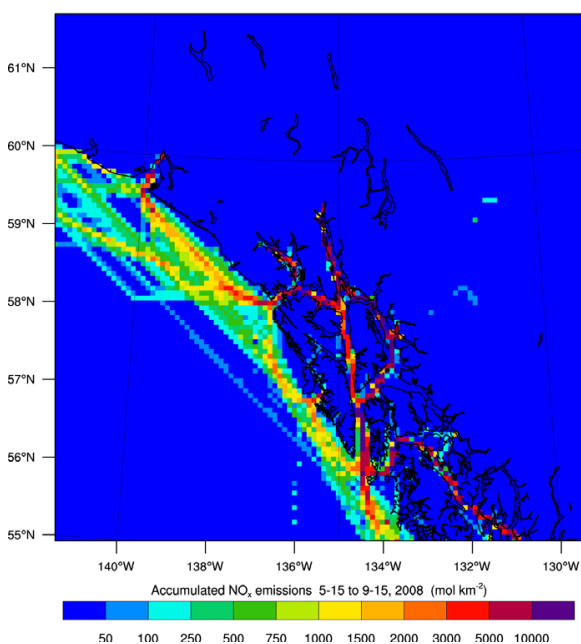

(e)

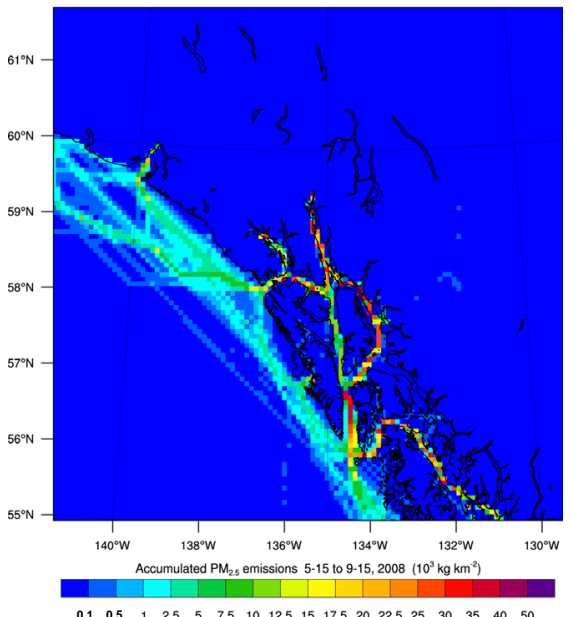

(b)

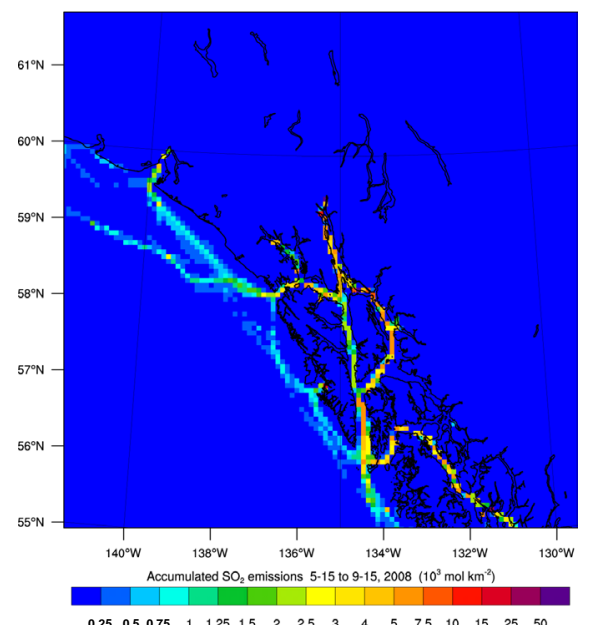

(d)

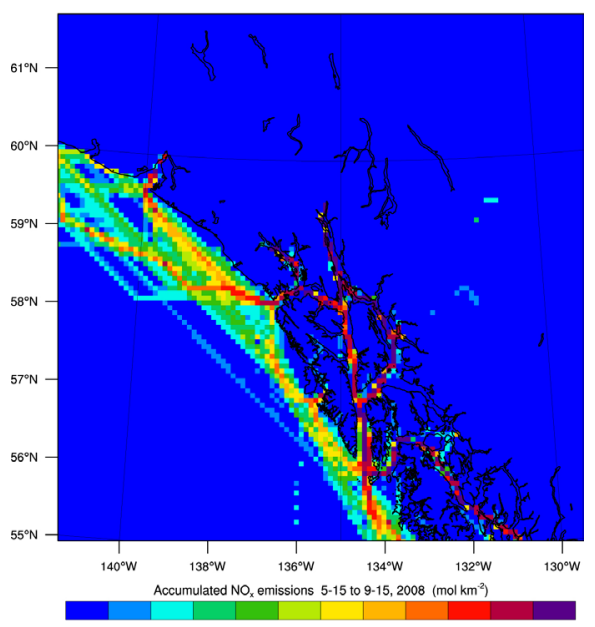

$50 \quad 100 \quad 250 \quad 500 \quad 750 \quad 1000 \quad 1500 \quad 2000 \quad 3000 \quad 5000 \quad 10000$

(f)

Figure 2. Spatial distribution of tourist-season accumulated cruise-ship emissions in Glacier Bay as obtained from ((a), (c), (e)) REF, and ((b), (d), (f)) QTA for (a), (b) $\mathrm{PM}_{10}$, (c), (d) $\mathrm{SO}_{2}$, and (e), (f) $\mathrm{NO}_{\mathrm{x}}$. CLN has no ship emissions. 
day. Identical idealized profiles of clean air background concentrations served as lateral boundary conditions in all three simulations. This design ensured that any differences in atmospheric trace-gas and particulate-matter concentrations, visibility as well as in meteorological fields between CLN and REF, CLN and QTA, as well as REF and QTA were only due to cruise-ship emissions.

The reference simulation was evaluated by means of twice-daily radiosonde data at Yakutat and hourly observations of $2 \mathrm{~m}$ temperature, $2 \mathrm{~m}$ dewpoint temperature, $10 \mathrm{~m}$ wind speed, and wind direction from 31 land and 11 buoy sites [11]. WRF/Chem performed well in predicting the vertical temperature profiles with overall bias (simulated minus observed), root-mean-square error (RMSE) and correlation (R) of $0.1^{\circ} \mathrm{C}, 1.8^{\circ} \mathrm{C}$, and 0.84 , respectively. A cold bias of $-1.4^{\circ} \mathrm{C}$ to $-0.3^{\circ} \mathrm{C}$ occurred within the first $600 \mathrm{~m}$ above ground. Over the entire vertical profile and all profiles of the season, dewpoint-temperature bias, RMSE and $\mathrm{R}$ were $0.8^{\circ} \mathrm{C}, 4.6^{\circ} \mathrm{C}$ and 0.60 , respectively. Below $1500 \mathrm{~m}$, dewpoint-temperature biases amounted $0.2^{\circ} \mathrm{C}$ to $1.2^{\circ} \mathrm{C}$. Overall wind-speed bias, RMSE and R amounted to $\sim 0 \mathrm{~m} \cdot \mathrm{s}^{-1}, 4.13 \mathrm{~m} \cdot \mathrm{s}^{-1}$ and 0.69 . Correlation R increased with increasing height. In the lower ABL, WRF/Chem often underestimated wind speed by up to $1.2 \mathrm{~m} \cdot \mathrm{s}^{-1}$ due to subgrid-scale channeling effects. Over the entire vertical profile and all profiles, wind-direction bias, RMSE and correlation were $-12^{\circ}, 9^{\circ}$ and 0.66 , respectively [11].

WRF/Chem captured the temporal evolutions of spatial mean $2 \mathrm{~m}$ air and $2 \mathrm{~m}$ dewpoint temperatures well, and those of $10 \mathrm{~m}$ wind speed and direction acceptably [11]. On average over all surface sites and the tourist season, biases of $2 \mathrm{~m}$ air and $2 \mathrm{~m}$ dewpoint temperatures, $10 \mathrm{~m}$ wind speed and $2 \mathrm{~m}$ relative humidity were $-0.6^{\circ} \mathrm{C}, 0.2^{\circ} \mathrm{C}, 1.75 \mathrm{~m} \cdot \mathrm{s}^{-1}$ and $2 \%$ (absolute), respectively. Performance varied among months.

\subsection{Analysis}

The analysis of the impacts of increased quotas on air quality and visibility focused generally on Glacier Bay National Park and Preserve and specifically on Glacier Bay proper (the main fjord area that cruise ships target for itineraries).The total increase in ship emissions into the region and Glacier Bay was determined (Figure 2, Table 1). Daily mean concentrations over the tourist season were calculated for CLN, REF and QTA.

We compared the visibility and air-quality relevant concentrations obtained by REF to those obtained by CLN to assess the impacts of current cruise-ship emissions. Comparison of these quantities gained by REF and QTA served to gain insight into the impacts of increased quotas.

Relative humidity contributes to the reduction of extinction by swelling of soluble sulfates and nitrates [39], while wind speed affects transport of pollutants. Therefore, we examined the relations of meteorological quantities, particular matter concentrations and visibility to understand the governing processes for degraded visibility in Glacier Bay.

The haze index $(H I)$ was determined from the WRF/Chem data at ship-height as described by [12]. HI values close to 0 deciview (dv) represent pristine conditions under Rayleih scattering conditions, i.e. HI increases as visibility degrades. Comparisons of the HI values of REF and CLN or QTA and CLN permit separation of meteorology and emission-related visibility degradation. Differences were tested for significance at the $95 \%$ confidence level by a two-tailed Student t-test. The word significant only occurs in this context hereafter.

\section{Results}

\subsection{Meteorology}

In 2008, winds were on average relatively calm in the first half of the season (cf. Figure 3(a)). The season

Table 1. Total cruise-ship emissions in Glacier Bay for the tourist season assuming the 2008 activity (REF), and increased quota of entries into Glacier Bay of two ships per day for May 15 to September 15 (QTA). No emissions except biogenic emissions were assumed for CLN.

\begin{tabular}{ccccccc}
\hline & \multicolumn{5}{c}{ Season accumulated emissions for Glacier Bay } \\
\cline { 2 - 7 } Simulation & $\begin{array}{c}\mathrm{SO}_{2} \\
\left(\mathrm{~mol} \cdot \mathrm{km}^{-2}\right)\end{array}$ & $\begin{array}{c}\mathrm{NO}_{\mathrm{x}} \\
\left(\mathrm{mol} \cdot \mathrm{km}^{-2}\right)\end{array}$ & $\begin{array}{c}\mathrm{NH}_{3} \\
\left(\mathrm{~mol} \cdot \mathrm{km}^{-2}\right)\end{array}$ & $\begin{array}{c}\mathrm{VOC} \\
\left(\mathrm{mol} \cdot \mathrm{km}^{-2}\right)\end{array}$ & $\begin{array}{c}\mathrm{PM}_{2.5} \\
\left(10^{-3} \mathrm{~kg} \cdot \mathrm{km}^{-2}\right)\end{array}$ & $\begin{array}{c}\mathrm{PM}_{10} \\
\left(10^{-3} \mathrm{~kg} \cdot \mathrm{km}^{-2}\right)\end{array}$ \\
\hline REF & 780.7 & 4349.9 & 270.6 & 100.7 & 2.0 & 0.22 \\
\hline
\end{tabular}




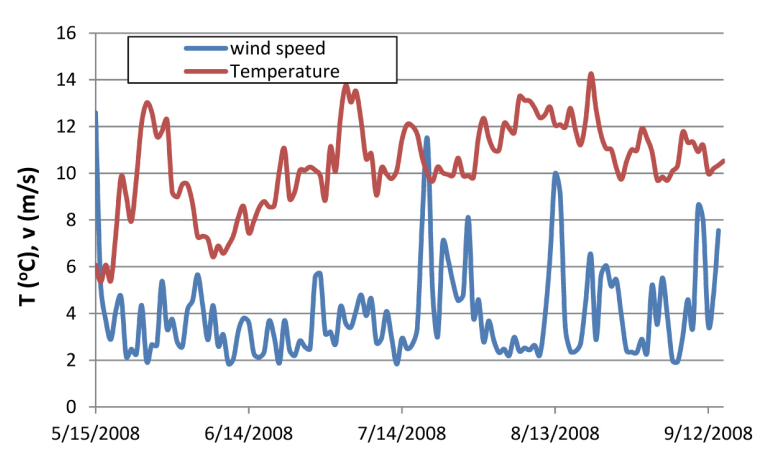

(a)

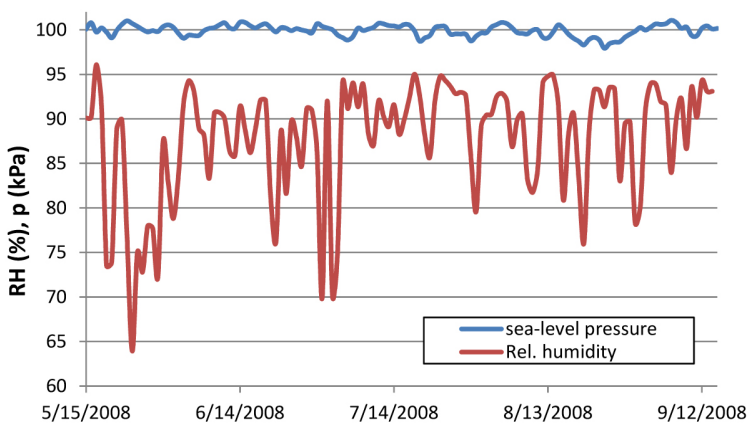

(b)

Figure 3. Temporal evolution of daily means averaged over the Glacier Bay proper of (a) $2 \mathrm{~m}$ air temperature and $10 \mathrm{~m}$ wind speed, and (b) sea-surface pressure and $2 \mathrm{~m}$ relative humidity as obtained by REF for the 2008 tourist season. Curves for CLN, and QTA marginally differed from those of REF over most of the season (therefore not shown).

started out cool followed by a warm episode. After a short cold snap, temperatures increased over summer with absolute day-to-day variations of daily means up to about $\pm 5^{\circ} \mathrm{C}$. September daily means averaged over Glacier Bay ranged between $9.7^{\circ} \mathrm{C}$ and $11.9^{\circ} \mathrm{C}$. Except for four short events early in the season, bay-wide daily mean relative humidity always exceeded 75\% (cf. Figure 3(b)). As the season progressed, relative humidity tended to increase as more cyclones reached Glacier Bay.

Radiation-cloud-aerosol interactions may affect meteorological quantities [25] [40]. Thus, simulated meteorological quantities showed differences between the simulations on an hourly basis, locally at various heights in Southeast Alaska. Typically, absolute values of differences between CLN and QTA or CLN and REF were largest in the downwind of areas with high emissions of radiative active pollutants and/or water-uptaking aerosols in QTA and REF, respectively.

In Glacier Bay, typically, absolute differences $|\mathrm{CLN}-\mathrm{REF}|$ and $|\mathrm{CLN}-\mathrm{QTA}|$ in near-surface meteorological quantities exceeded those of |REF-QTA|. Hourly absolute differences varied in time and space in Glacier Bay. The absolute differences in meteorological quantities remained relatively low, because the concentrations of pollutants relevant in the interactions were relatively low as compared to the concentrations in the studies on aerosols over the continental US [41], on Alaska wildfire-smoke impacts [42], or on severe haze in eastern China [43]. Furthermore, our study only considered cruise-ship and biogenic emissions.

Daily bay-averaged means of $2 \mathrm{~m}$ air temperature, $2 \mathrm{~m}$ relative humidity, $10 \mathrm{~m}$ wind speed, and sea-level pressure differed among CLN, REF, and QTA on the order of about $\pm 0.1^{\circ} \mathrm{C}, \pm 1 \%$, less than $\pm 1 \mathrm{~cm}$ and $\pm 1 \mathrm{hPa}$, respectively for most of the season. This result was partly due to increases and decreases in time and space canceling each other out. However, over the Glacier Bay water, temporally maximum differences ranged between $-1.1^{\circ} \mathrm{C}$ and $0.8^{\circ} \mathrm{C},-22 \%$ and $5 \%,-66 \mathrm{~cm} \cdot \mathrm{s}^{-1}$ and $87 \mathrm{~cm} \cdot \mathrm{s}^{-1}$, and $-1.8 \mathrm{hPa}$ and $0.8 \mathrm{hPa}$ among simulations. Since the impacts of increased entry quotas on radiation-cloud-aerosol interactions were beyond the scope of this study, they are not discussed any further.

\subsection{Emissions}

In 2008, 16 different cruise ships visited Glacier Bay. These ships varied in terms of passenger volume, main and auxillary engine types, fuel types used, load factors, and maximum cruise speeds. Thus, their emissions differed. Furthermore, their emissions differed in terms of cruise speed, manuvering, total time in the bay and berthing durations. Thus, daily emissions were not just a function of the volume of ships, but also which ship(s) entered Glacier Bay and their operations once in the bay.

The cruise ships of the two major companies (group 1, group 2) and the cruise ships of all the other companies (group 3) visiting Glacier Bay encompassed ships of different sizes. For simplicity, the additional ships in each of the three groups (cf. Section 2.2) were assumed to be of the same type as the cruise ship with the most entrances in that group in 2008.

Compared to an additional cruise ship of group 1, the typical emissions in Glacier Bay per visit of an additional cruise ship of group 2 were 51\%, 38\%, 418\%, 35\%, 61\%, and 37\% higher for PM, VOC, $\mathrm{SO}_{2}, \mathrm{NO}_{\mathrm{x}}, \mathrm{CO}$, and $\mathrm{NH}_{3}$, respectively. The additional cruise ship of group 3 emitted $24 \%, 27 \%, \sim 1 \%$, 24\%, 36\% and $24 \%$ less 
$\mathrm{PM}, \mathrm{VOC}, \mathrm{SO}_{2}, \mathrm{NO}_{\mathrm{x}}, \mathrm{CO}$, and $\mathrm{NH}_{3}$ than the ship of group 1 . The cruise ship of group 3 emitted $16 \%, 20 \%, 19 \%$, $18 \%, 22 \%$ and $17 \%$ less $\mathrm{PM}, \mathrm{VOC}, \mathrm{SO}_{2}, \mathrm{NO}, \mathrm{CO}$, and $\mathrm{NH}_{3}$ than the cruise ship of group 2 (Figure 1).

These differences resulted from different ratios of fuel types used, and different engine sizes, load factors, cruise speeds, maximum cruise speed, cruise pattern, as well as bethering durations (for a detailed discussion see [12]). Compared to the additional cruise ship of group 1 the emissions per person on the additional ship of group 2 (3) are $38 \%$ higher (18\% lower). The emissions per person on the additional cruise ship of group 3 are $40 \%$ lower than for the additional ship of group 2. Note that the ship of group 2 (3) has the lowest (highest) capacity of passengers plus crew.

Table 1 gives the season-accumulated emissions into Glacier Bay under the REF and QTA scenarios. With the above-described quotas, daily mean emissions in Glacier Bay increased by $41 \%, 41 \%, 38 \%, 23 \%$, 38\%, and $36 \%$ for $\mathrm{PM}_{10}, \mathrm{PM}_{2.5}, \mathrm{SO}_{2}, \mathrm{VOC}, \mathrm{NO}$, and $\mathrm{NH}_{3}$, respectively.

During the "peak season", six or more cruise ships are a common occurance in some areas of Southeast Alaska [44]. In our study, increased quotas for Glacier Bay entrances meant in QTA increased inbound and outbound traffic in the area covered by the model domain (Figure 1). In the region covered by the model domain, the increased quota meant additional emissions from up to six cruise ships lasting for three to five days per additional cruise-ship depending on their routes.

In QTA, daily emissions increased the highest when six additional ships cruised in Southeast Alaska. Seasonaccumulated cruise-ship emissions increased not only in Glacier Bay (Figure 4), but also along the coast of the Gulf of Alaska, in Icy Strait and the Inside Passage (Figure 2).

Only on seven days of the tourist season, QTA and REF had the same number of cruise ships in the model domain, i.e. identical emissions across the domain in QTA and REF (cf. e.g. Figure 4). However, QTA and REF concentrations differed on these seven days due to different emissions on the preceding days (cf. e.g. Figure $5(\mathrm{~b}))$.

In Glacier Bay, daily-accumulated emissions varied across the season (Figure 4) due to different cruisingspeeds and berthing times for glacier viewing [12] as well as different combinations of visiting ship types and

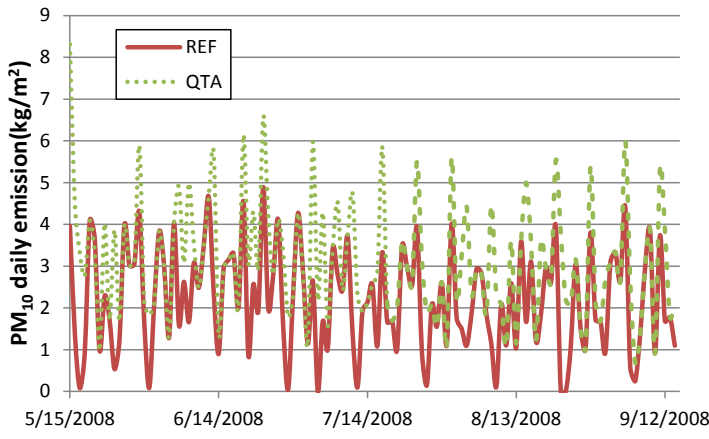

(a)

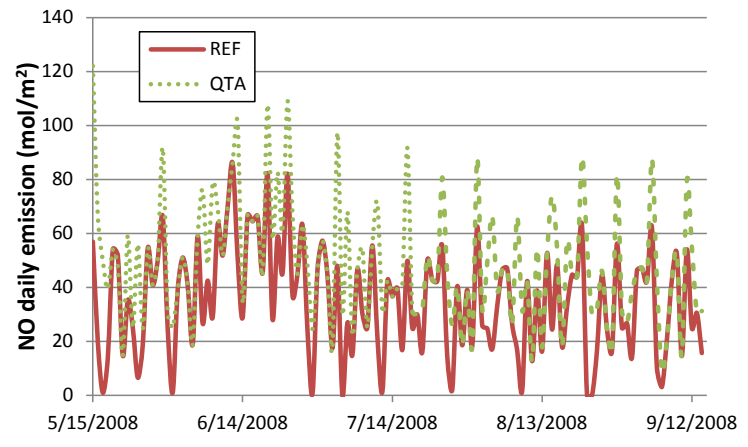

(c)

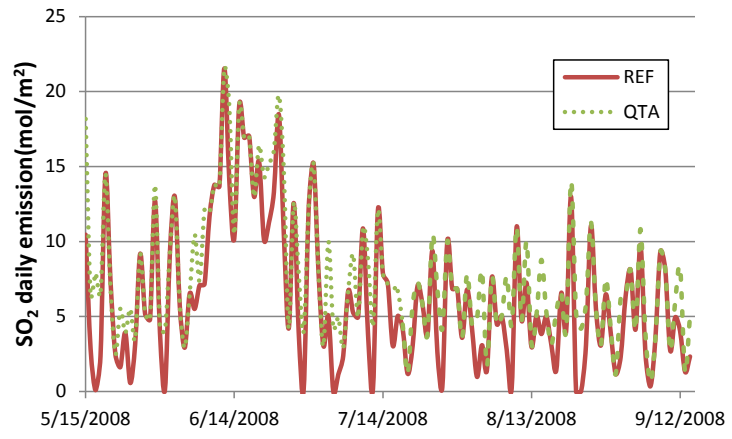

(b)

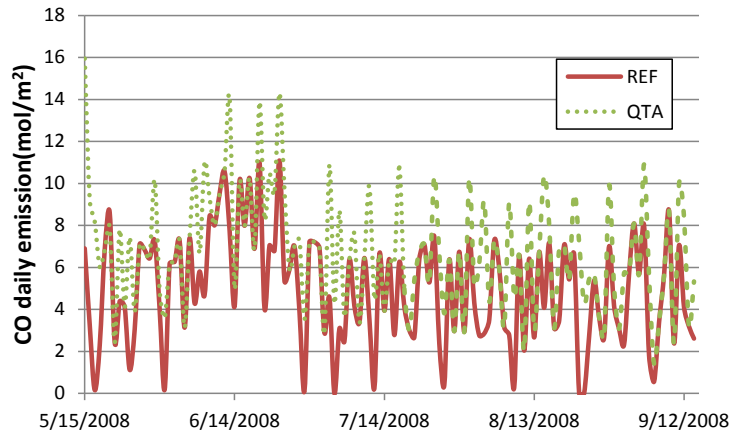

(d)

Figure 4. Daily accumulated cruise-ship emissions of (a) $\mathrm{PM}_{10}$, (b) $\mathrm{SO}_{2}$, (c) $\mathrm{NO}$ and (d) CO in Glacier Bay for REF and QTA. Note that cruise ships traveling Icy Strait between Lemesurier Island and Pleasant Island thereby passing the Glacier Bay entrance area were included in the calculation of accumulated emissions in Glacier Bay. 


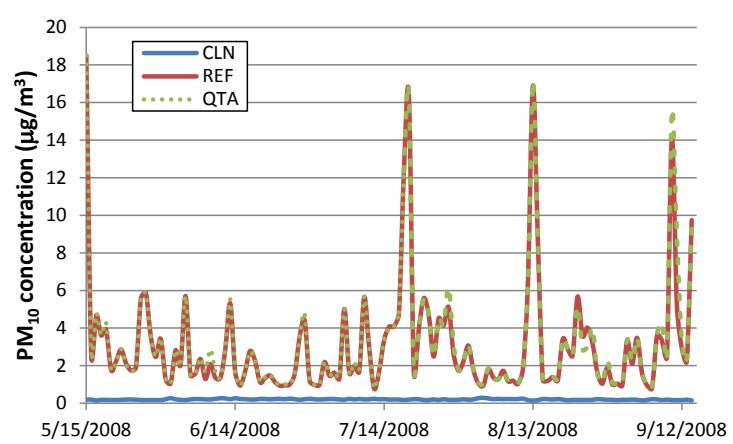

(a)

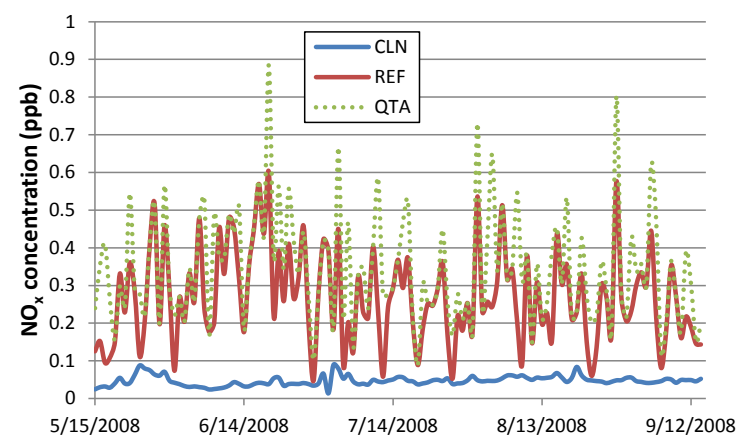

(c)

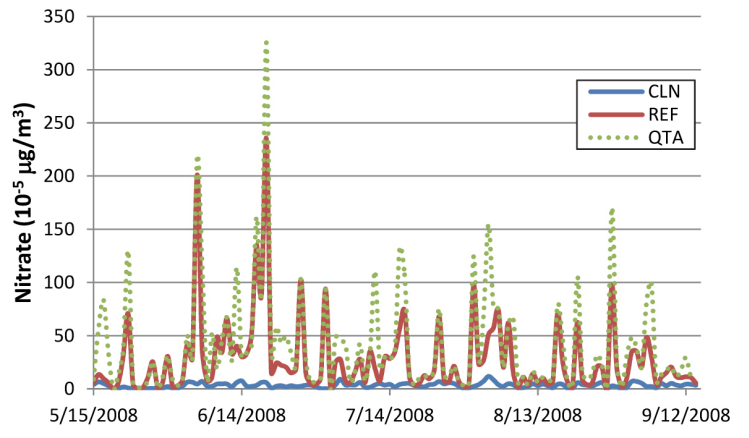

(e)

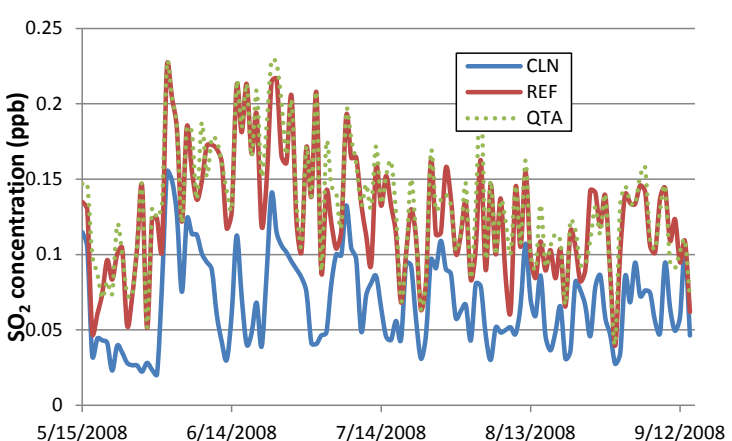

(b)

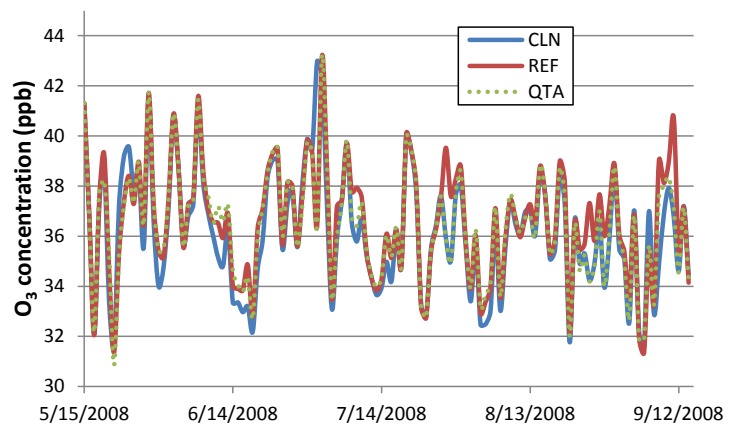

(d)

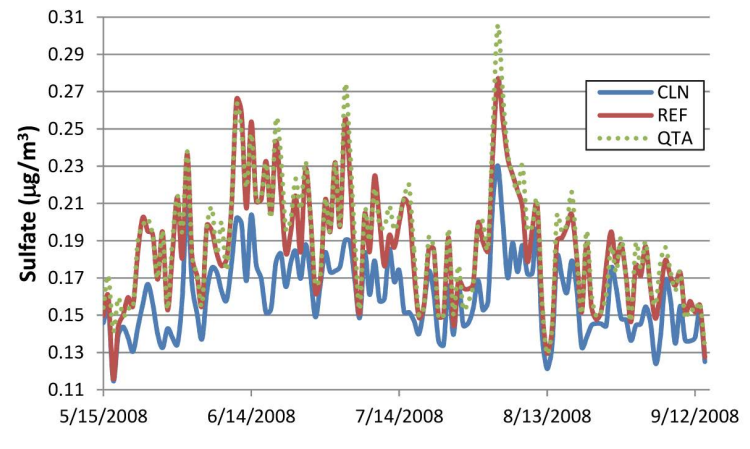

(f)

Figure 5. Daily mean concentrations of (a) $\mathrm{PM}_{10}$, (b) $\mathrm{SO}_{2}$, (c) $\mathrm{NO}_{\mathrm{x}}$, (d) $\mathrm{O}_{3}$, (e) nitrate aerosols, and (f) sulfate aerosols in Glacier Bay for CLN, REF and QTA over the length of the tourist season.

their engine powers [45]. For example, in mid June, several of the largest cruise ships visited the park on consecutive days resulting in elevated emissions as compared to other periods when the same number of cruise ships visited.

Comparing all daily-accumulated QTA emissions occurring on days with zero emissions in REF to each other indicates the variability of confounding factors in emissions. Days without cruise-ship visits show as days with zero emissions in Figure 4. In QTA, on some days, daily increases in $\mathrm{PM}_{10}$, and $\mathrm{PM}_{2.5}$ emissions into Glacier Bay amounted up to $1.6 \%$, and $2.6 \%$ of the seasonal total accumulated emissions in REF.

In 2008, less cruise-ship visits occurred during the May and September "shoulder season” (averaging one per day or less) than during the June to August "peak season" (up to two per day). Consequently, with respect to time, accumulated emissions increased stronger at the beginning and towards the end of the tourist season than during the "peak season” (Figure 4).

\subsection{Concentrations}

In CLN, particulate matter was mainly $\mathrm{PM}_{2.5}$ from sea-salt. In the fjords, and Icy Strait, season-mean $\mathrm{PM}_{2.5}$ 
( $\mathrm{PM}_{10}$ ) concentrations at ship height ranged between $0.7(0.2)$ and $0.9(0.3) \mu \mathrm{g} \cdot \mathrm{m}^{-3}$ (cf. Figure 6(a)). Over Lynn Chanel and Chatham Strait, $\mathrm{PM}_{2.5}$ concentrations reached up to $2.5 \mu \mathrm{g} \cdot \mathrm{m}^{-3}$. Along the coast, mean $\mathrm{PM}_{2.5}$ concentrations varied between 0.6 and $0.75 \mu \mathrm{g} \cdot \mathrm{m}^{-3}$. Farther out in the Gulf of Alaska and inland mean $\mathrm{PM}_{2.5}$ concentrations decreased with increasing distance from the coast. In CLN, daily mean $\mathrm{PM}_{10}$ concentrations varied within their magnitude in response to the weather conditions (Figure 5(a), Figure 3).

In REF and QTA, Glacier Bay daily mean $\mathrm{PM}_{10}$ concentrations remained below $6 \mu \mathrm{g} \cdot \mathrm{m}^{-3}$ except for five occasions (Figure 5(a)). On these days, the means ranged from about $10 \mu \mathrm{g} \cdot \mathrm{m}^{-3}$ to more than $18 \mu \mathrm{g} \cdot \mathrm{m}^{-3}$. These days also had highest $\mathrm{PM}_{2.5}$ concentrations (not shown). $\mathrm{PM}_{2.5}$ concentrations often showed more peaks than $\mathrm{PM}_{10}$ concentrations for both REF and QTA. Occassionally, hourly $\mathrm{PM}_{2.5}$ concentrations exceeded the daily means by threefold.

In QTA, daily mean $\mathrm{PM}_{10}$ and $\mathrm{PM}_{2.5}$ concentrations typically increased on days with additional cruise-ship

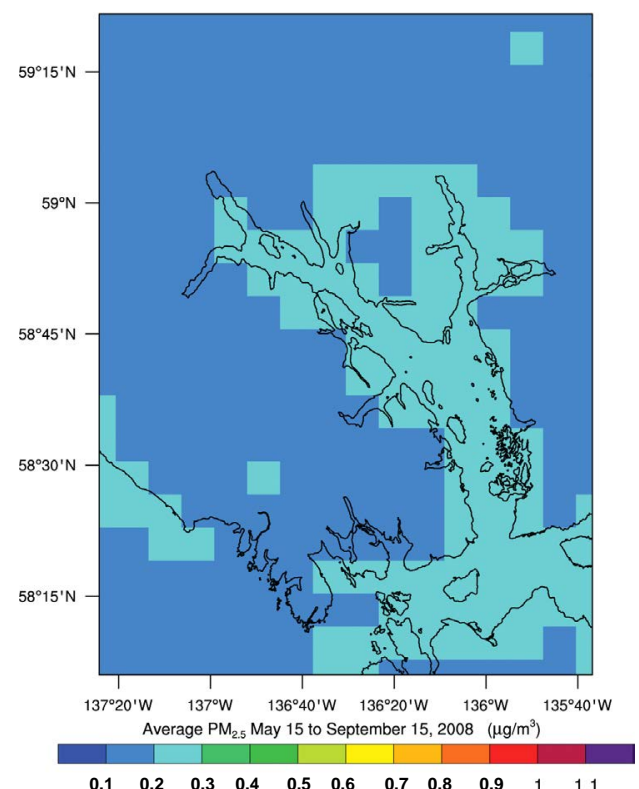

(a)

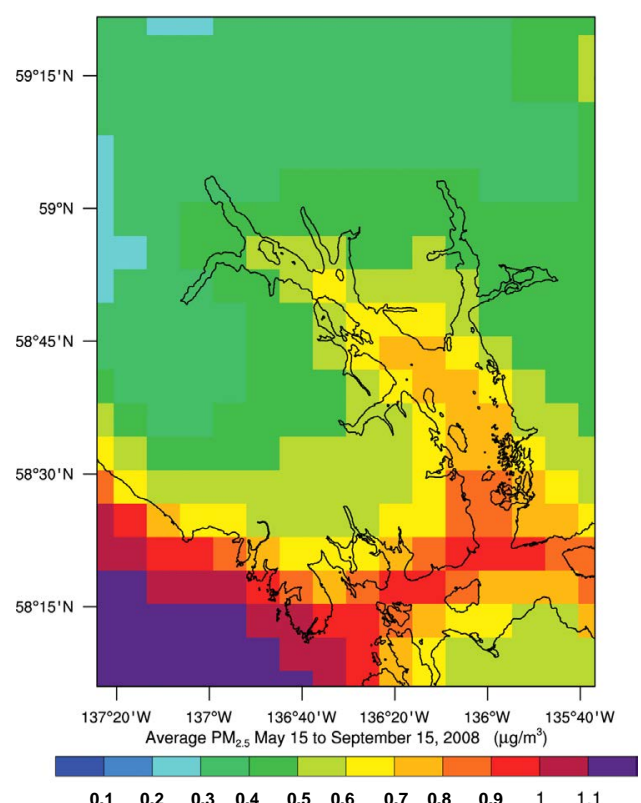

(c)

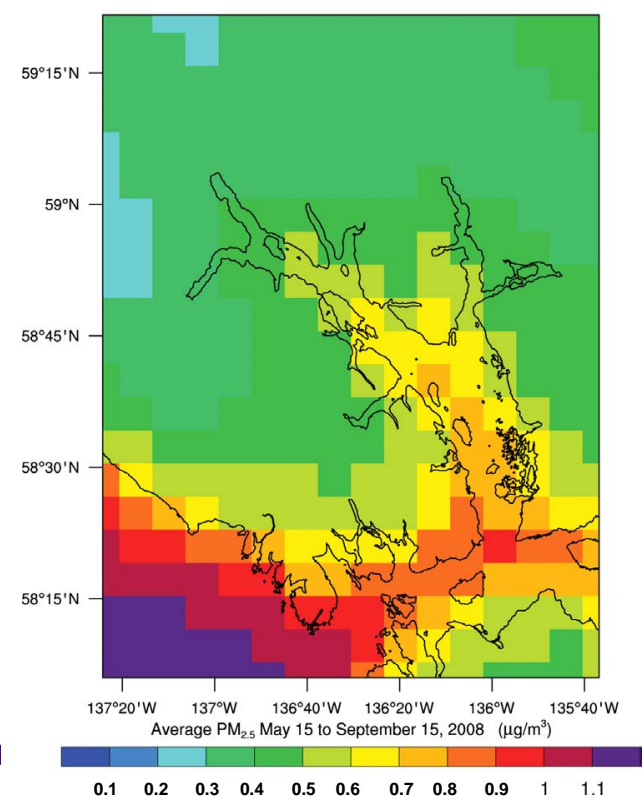

(b)

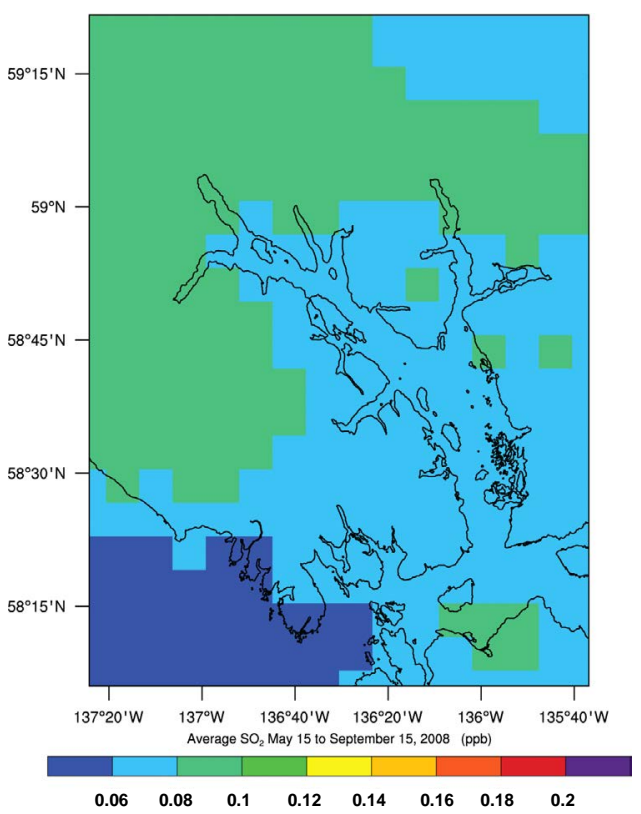

(d) 


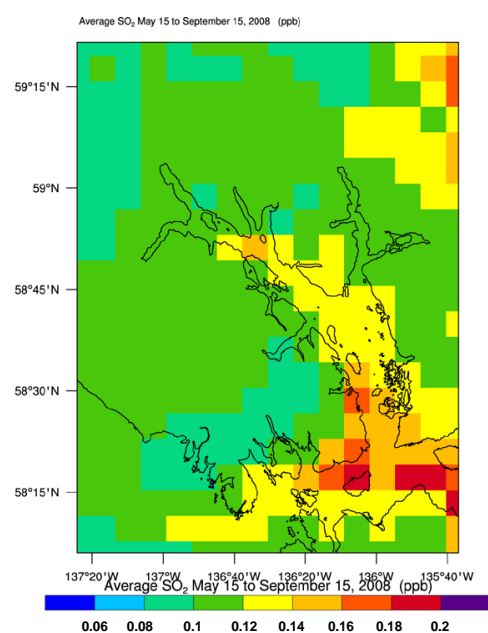

(e)

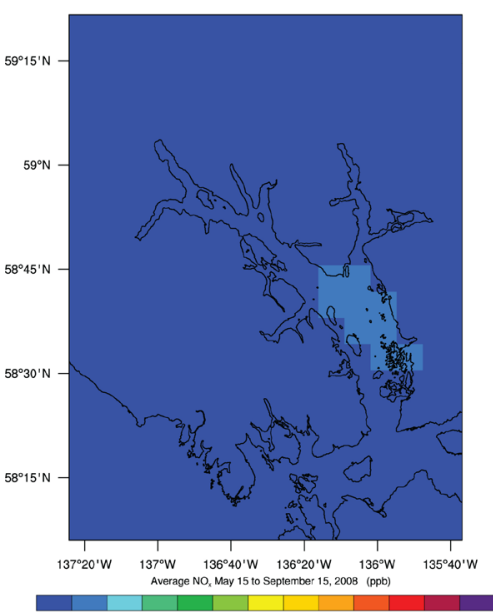

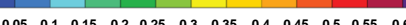

(g)

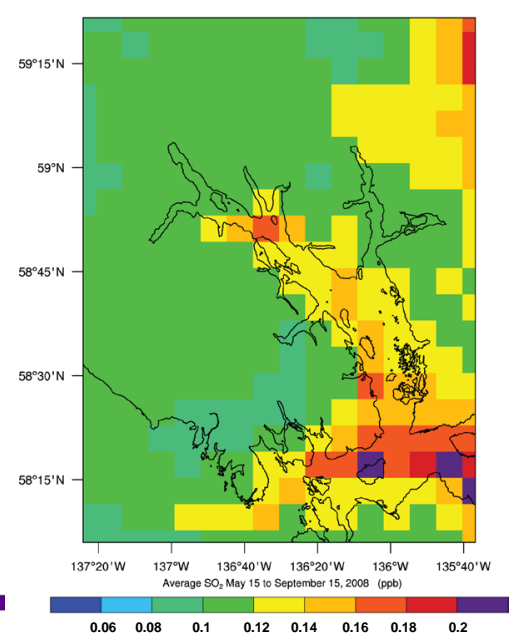

(f)

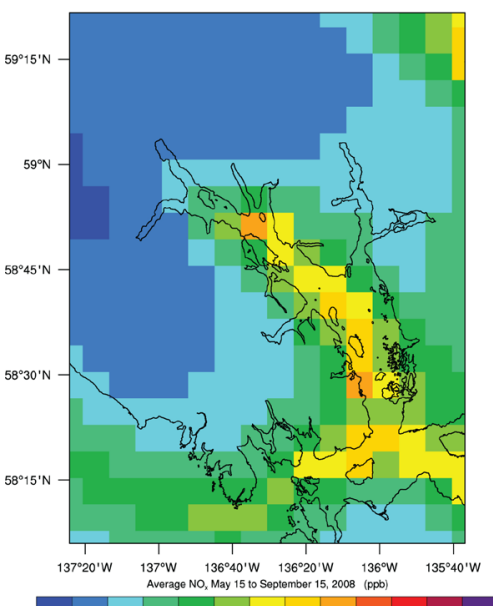

$\begin{array}{lllllllllllll}0.05 & 0.1 & 0.15 & 0.2 & 0.25 & 0.3 & 0.35 & 0.4 & 0.45 & 0.5 & 0.55 & 0.6\end{array}$

(h)

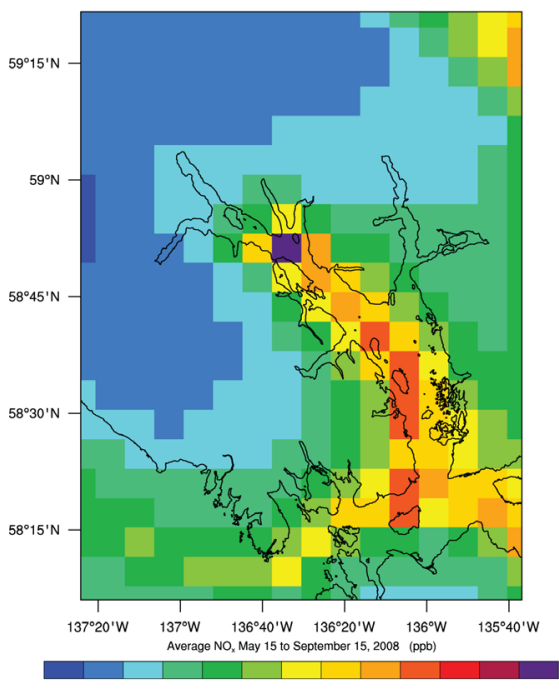

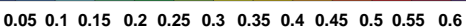

(i)

Figure 6. Zoom-in on the spatial distributions of tourist-season mean concentrations in Glacier Bay for ((a), (c), (e)) CLN, ((b), (e), (h)) REF, and ((d), (f), (i)) QTA for ((a)-(c)) $\mathrm{PM}_{2.5}$, ((d)-(f)) $\mathrm{SO}_{2}$, and ((g)-(i)) $\mathrm{NO}_{\mathrm{x}}$. 
visits with largest increases on days when two additional cruise ships entered Glacier Bay, i.e. when REF had no visits on that day (cf. Figure 4(a), Figure 5(a)). At the end of August, daily mean $\mathrm{PM}_{10}$ concentrations decreased for a short time in Glacier Bay despite the additional visits in QTA. More small particles competed for precursor gases in QTA than REF, and, hence, fewer particles reached sizes beyond $2.5 \mu \mathrm{m}$ in diameter. Consequently, despite enhanced precursor gas and PM emissions in QTA, $\mathrm{PM}_{10}$ concentrations decreased as $\mathrm{PM}_{2.5}$ concentrations increased. On some days early in the season, $\mathrm{PM}_{2.5}$ decreased despite increased emissions while $\mathrm{PM}_{10}$ increased due to increased emissions plus more $\mathrm{PM}_{2.5}$ growing to $\mathrm{PM}_{10}$ due to the additional precursor emissions. These findings suggest that additional emissions can alter the fine-to-coarse particle ratios in both directions.

There were also some notable, spatially specific differences in $\mathrm{PM}_{10}$ concentrations between REF and QTA. For example, at the mouth of Glacier Bay, in the mid-bay and in front of the glacier as well as along the shores of the Gulf of Alaska, season-mean PM concentrations increased up to about $0.1 \mu \mathrm{g} \cdot \mathrm{m}^{-3}$ throughout the ABL in response to the increased entry quotas (cf. Figure 6(b), Figure 6(c)).

In CLN, no emission sources for $\mathrm{SO}_{2}$ existed. Thus, $\mathrm{SO}_{2}$ concentrations in Glacier Bay represented pristine air background values (cf. Figure 5(b), Figure 6(d)). Dry and wet deposition, chemical reactions and gas-to-particle conversion are sinks for $\mathrm{SO}_{2}$. These processes depend, among other things, on the meteorological conditions [14]. For example, chemical reaction rates increase nonlinear with increasing temperature; Solubility of gases in droplets increases with decreasing temperature and droplet size. Besides the micrometeorological conditions, dry deposition depends on surface type [46].

The removal processes and physio-chemical fates modify the spatial-temporal distribution of $\mathrm{SO}_{2}$. Consequently, in CLN on season-average, near-surface mean $\mathrm{SO}_{2}$ concentrations were highest over the St. Elias and Coast Mountains (0.8 ppb to $1.6 \mathrm{ppb}$ ) due to the low temperatures there (Figure 6(d)). In the Gulf of Alaska away from the coast, $\mathrm{SO}_{2}$ concentrations were less than $0.4 \mathrm{ppb}$. Elsewhere near-surface $\mathrm{SO}_{2}$ concentrations ranged between $0.7 \mathrm{ppb}$ and $0.8 \mathrm{ppb}$. On average, dry deposition of $\mathrm{SO}_{2}$ was strongest over the Tongass National Forest (up to $50 \mathrm{~g} \cdot \mathrm{km}^{-2} \cdot \mathrm{h}^{-1}$ ).

In Glacier Bay, synoptic and surface conditions governed $\mathrm{SO}_{2}$ concentrations in CLN (cf. Figure 3, Figure 5(b), Figure 6(d)). In REF and QTA, $\mathrm{SO}_{2}$ concentrations kept the broad patterns of synoptic-scale related decreases and increases, but at enhanced concentrations due to ship emissions (Figures 1-3, Figure 4(b), Figure 5(b), Figure 6(e), Figure 6(f)). In Glacier Bay, the cruising to and berthing in front of the glaciers were obvious in the $\mathrm{SO}_{2}$ distributions at ship level and through the ABL in REF and QTA. At ship level, increased quota increased $\mathrm{SO}_{2}$ concentrations up to about $20 \mathrm{ppt}$ on season-average, particularly along the cruise path and in front of the glaciers. Except for a few occasions in early June, late August and around September $10, \mathrm{SO}_{2}$ concentrations in QTA exceeded those of REF.

These exceptions of decreased $\mathrm{SO}_{2}$ concentrations despite increased $\mathrm{SO}_{2}$ emissions (cf. e.g. Figure 4(b), Figure 5(b)) resulted from shifts in the competition of $\mathrm{SO}_{2}$ and $\mathrm{NO}_{\mathrm{x}}$ for $\mathrm{NH}_{3}$ in the formation of aerosols. Other emission-impact studies also reported such shifts (e.g. [47] [48]). For example, ammonimum nitrate forms under low sulfate, but ammonia and nitric acid-rich conditions. Ammonimum and nitrate exist in the aerosol phase when enough ammonia and nitric acid exist for saturation in the gas phase. Sulfuric acid also has an extremely low vapor pressure. Ammonium-sulfate formation needs two ammonia molecules for one aerosol to form. Thus, abondance of $\mathrm{SO}_{2}$ shifts aerosol formation towards more amonimum-sulfate, and less amonimum-nitrate aerosols.

In contrast to $\mathrm{SO}_{2}, \mathrm{NO}_{\mathrm{x}}$ has two natural sources within the model domain even in absence of anthropogenic emissions (CLN). Soil bacteria emit $\mathrm{NO}_{\mathrm{x}}$ depending on the soil-temperature and soil-moisture conditions as part of their metabolic activities (e.g. [34] [46]). In the atmosphere, peroxiacetyl nitrate (PAN) is a reservoir for $\mathrm{NO}_{\mathrm{x}}$ that releases (takes up) $\mathrm{NO}_{\mathrm{x}}$ as temperatures go up (down) [14]. This means that in equilibrium between $\mathrm{NO}_{\mathrm{x}}$ and PAN, $\mathrm{NO}_{\mathrm{x}}(\mathrm{PAN})$ concentrations are higher (lower) during warm than cool weather [14].

Season mean $\mathrm{NO}_{\mathrm{x}}$ concentrations followed the topographic elevation in CLN with lowest values over the glaciers of Glacier Bay and highest over the Gulf of Alaska and the low elevations inland (e.g. Figures 6(g)-(i)). The opposite was true for PAN (not shown). Furthermore, $\mathrm{NO}_{\mathrm{x}}$ concentrations increased/decreased with the advection of warm/cold air (cf. e.g. Figure 3(a), Figure 5(c)).

In contrast to CLN, this general chemical behavior was less obvious in REF and QTA. The cruise-ship emissions disturbed the PAN-NO ${ }_{x}$ equilibrium and it took time for the equilibrium to re-establish. In QTA, throughout the season, $\mathrm{NO}_{\mathrm{x}}$ concentrations were higher on days with additional entries in Glacier Bay than in REF (cf. 
Figure 4(c), Figure 5(c)). Typically, QTA PAN-concentrations exceeded those of REF and CLN (Figure 5(c)). Increased quota increased season-mean PAN concentrations up to 20 ppt over Glacier Bay (not shown).

In CLN, biogenic emissions were the only source of VOCs. In CLN, VOC concentrations were high over the Tongass National Forest and low over glaciers and the Gulf of Alaska (not shown). In CLN, REF, and QTA, VOC concentrations increased as summer progressed. While VOC minima matched up well among the three simulations, in REF and QTA, the ship emissions governed the maxima with the latter having higher concentrations on days with additional entries than the former (not shown).

The cruise-ship emissions of $\mathrm{NO}_{\mathrm{x}}$ and VOCs also affected the ozone $\left(\mathrm{O}_{3}\right)$ concentrations and season-mean $\mathrm{O}_{3}$ concentrations were lowest in CLN (Figure 5(d), Table 2). In the unpolluted atmosphere of CLN, less shortwave radiation was absorbed by aerosols during clear sky conditions. Consequently, actinic fluxes exceeded those of REF or QTA meaning more photolysis occurred in CLN than REF or QTA. Similar to $\mathrm{SO}_{2}$, the seasonmean $\mathrm{NO}_{\mathrm{x}}$ distribution reflected the cruise paths and berthing in front of the glaciers (Figure 6(h), Figure 6(i)) at ship level and throughout the ABL. In QTA, season-mean near-surface $\mathrm{NO}_{\mathrm{x}}$ concentrations increased up to about 50 ppt in these locations, in Icy Strait and along the coast of the Gulf of Alaska.

\subsection{Deposition}

Wet and dry deposition and atmospheric removal of aerosols are of concern for land and marine ecosystems. Acidic deposition may decrease the $\mathrm{pH}$-values of waters. Since WRF/Chem does not have an ocean model, it cannot provide information on how the deposition fluxes would change the $\mathrm{pH}$-values of the waters. However, WRF/Chem provided information on the amount of pollutants deposited into waters, onto glacier, and on land. In nature, in the case of deposition of soot on glaciers, increased quotas may affect the radiation budget. However, the simulations did not consider this impact.

Changes in deposition fluxes contributed to the nonlinear responses of concentrations to the emission increases. On average, deposition of PM was largest over forests, and lowest over water in all simulations. It was lowest in CLN as here PM only had natural sources (e.g. sea-spray, gas-to-particle conversion). In REF, average deposition of PM over forests reached locally up to $4 \mathrm{~kg} \cdot \mathrm{km}^{-2} \cdot \mathrm{h}^{-1}$, and remained less than $0.4 \mathrm{~kg} \cdot \mathrm{km}^{-2} \cdot \mathrm{h}^{-1}$ into waters. In QTA, the season-mean PM deposition increased up to about $0.5 \mathrm{~kg} \cdot \mathrm{km}^{-2} \cdot \mathrm{h}^{-1}$ along the coasts and on the shores of Glacier Bay in QTA as compared to REF due to increased cruise-ship traffic.

Likewise, season-mean $\mathrm{SO}_{2}$ deposition increased up to $0.5 \mathrm{~g} \cdot \mathrm{km}^{-2} \cdot \mathrm{h}^{-1}$ in Glacier Bay in particular in the fjords of glacier viewing. However, due to advection of pollutants, notable increases also occurred in the areas of Glacier Bay where the NPS prohibits ship traffic. Along the southern shores of Icy Strait and the entrance of Glacier Bay both $\mathrm{SO}_{2}$ and $\mathrm{NO}_{2}$ deposition increased up to $10 \mathrm{~g} \cdot \mathrm{km}^{-2} \cdot \mathrm{h}^{-1}$, and about $5 \mathrm{~g} \cdot \mathrm{km}^{-2} \cdot \mathrm{h}^{-1}$, respectively, in QTA compared to REF (not shown).

\subsection{Visibility}

Relative humidity, $\mathrm{PM}_{10}$ and $\mathrm{NO}_{2}$ concentrations affect visibility [49]. The haze index $H I=10 \cdot \ln \left(0.1 \cdot b_{\text {ext }}\right)$ quantifies the perceived visibility as a function of light extinction, $b_{\text {ext }}$. Light extinction depends on the Rayleigh

Table 2. Statistics on concentrations of selected aerosol-precursor gases and particulate matter over Glacier Bay for CLN, REF, and QTA for the tourist season. Skewness and kurtosis are dimensionless (-.-).

\begin{tabular}{ccccccccccc}
\hline & \multicolumn{7}{c}{ Comparison of mean concentrations in Glacier Bay } \\
\cline { 2 - 10 } Statistics & \multicolumn{3}{c}{$\mathrm{SO}_{2}(\mathrm{ppb}) .(-.-)$} & \multicolumn{3}{c}{$\mathrm{NO}_{\mathrm{x}}(\mathrm{ppb}),(-.-)$} & \multicolumn{2}{c}{$\mathrm{PM}_{10}\left(\mu \mathrm{g} \cdot \mathrm{m}^{-3}\right),(-.-)$} \\
\cline { 2 - 10 } & CLN & REF & QTA & CLN & REF & QTA & CLN & REF & QTA \\
\hline Mean & 0.07 & 0.13 & 0.13 & 0.05 & 0.27 & 0.35 & 0.2 & 3.1 & 3.2 \\
StDev & 0.03 & 0.05 & 0.06 & 0.01 & 0.2 & 0.2 & 0.03 & 3.3 & 3.4 \\
Skewness & 0.571 & 1.931 & 1.843 & 0.929 & 2.640 & 2.567 & 0.574 & 2.846 & 2.768 \\
Kurtosis & -0.195 & 9.189 & 8.416 & 1.321 & 19.346 & 17.034 & 0.628 & 9.579 & 9.910 \\
Minimum & 0.02 & 0.02 & 0.02 & 0.02 & 0.03 & 0.03 & 0.14 & 0.16 & 0.16 \\
Maximum & 0.51 & 0.72 & 0.79 & 0.1 & 3.20 & 3.75 & 0.22 & 1.13 & 1.16 \\
\hline
\end{tabular}


scattering of $\mathrm{NO}_{2}$, relative humidity, the concentrations of sulfate, nitrate, organic carbon (OC), elemental carbon (EC), fine soil particles of aerodynamic diameters less than $2.5 \mu \mathrm{m}$, and coarse particulate matter (CM) of aerodynamic diameters between $2.5 \mu \mathrm{m}$ and $10 \mu \mathrm{m}$. Thus, any shifts in fine-to-coarse ratio of these aerosols affect visibility.

We calculated light extinction from the WRF/Chem results following [20] and used it to determine visibility at mean cruise-ship height as this is the elevation that may impact visitor experience. The US Environmental Protection Agency (EPA) usually calculates visibility at $1.8 \mathrm{~km}$ height [49]. However, due to the humidity of the maritime climate, the top of the ABL was often cloudy thereby blocking the view to this height.

In CLN, REF and QTA, high relative humidity was the main cause of low visibility (Figure 3(b), Figure 7(a)). At high relative humidity, soluble nitrates and sulfates swell thereby reducing extinction [49]. In all cases, visibility showed a degrading trend as summer progressed due to increasing relative humidity associated with more cyclones reaching Glacier Bay. Linear trends followed $H I_{C L N}(t)=0.006 \cdot t-244.1, H I_{R E F}(t)=0.0056 \cdot t-$ 217.58 , and $\mathrm{HI}_{\mathrm{QTA}}(t)=0.0059 \cdot t-231.98$ where $t$ is time. Haze indices were highly correlated with relative humidity $(\mathrm{R}=0.68)$ and $\mathrm{PM}_{2.5}(\mathrm{R}=0.66)$ in CLN. In CLN, all $\mathrm{PM}_{10}$ was less than $2.5 \mu \mathrm{m}$ in diameter, i.e. $\mathrm{PM}_{2.5}$. In REF and QTA, besides the emitted $\mathrm{PM}_{10}, \mathrm{PM}_{10}$ existed from particle growth by accumulation of precursor gases on natural and emitted $\mathrm{PM}_{2.5}$.

On average over Glacier Bay, CLN haze indices for the $20 \%$ best, median $(40 \%-60 \%)$ and $20 \%$ worst visibility days were $1.0,1.9$, and $2.9 \mathrm{dv}$, respectively. The mid points of these visibility ranges are the $10^{\text {th }}, 50^{\text {th }}$ and $90^{\text {th }}$ percentile, as which we addressed these ranges hereafter. In REF, the $10^{\text {th }}, 50^{\text {th }}$ and $90^{\text {th }}$ percentile of HI were 1.8, 3.0, and $5.2 \mathrm{dv}$, respectively [12]. Despite increased emissions, the $10^{\text {th }}, 50^{\text {th }}$ and $90^{\text {th }}$ percentile of HI of QTA and REF were the same. In all cases, worst visibility days coincided with high relative humidity (cf. Figure 3(b), Figure 7(a)).

At ship height, on average over Glacier Bay across the tourist season, mean HI were 1.9, 3.2, and $3.3 \mathrm{dv}$ in CLN, REF and QTA, respectively. This visibility is better than the 2018 target set by the US EPA for pristine areas. Whereas, season-mean haze indices varied marginally in space for CLN over Glacier Bay (Figure 8(a)), both REF and QTA showed a gradient of decreasing visibility from the glacier viewing fjords to the entrance of Glacier Bay. Close to the entrance, advection of pollutants from ships cruising thru Icy Strait contributed to reduced visibility (Figure 8(a)). In QTA, atmospheric transport increased HI in the Muir Inlet, an area in the upper east arm of the fjord void of cruise-ship traffic (cf. Figure 8(b), Figure 8(c)). Due to changes in concentrations (Figure 6), and deposition, HI decreased over the Brady Glacier in QTA as compared to REF (cf. Figure 8(b), Figure 8(c)).

It is clear that transport by wind can be an essential removal path for pollutants emitted by cruise ships in Glacier Bay. However, wind can also transport pollutants into Glacier Bay [11]. In REF, haze indices were highly correlated with wind speeds $(\mathrm{R}=0.83), \mathrm{PM}_{10}(\mathrm{R}=0.83)$, and $\mathrm{PM}_{2.5}$ concentrations $(\mathrm{R}=0.72)$. Correlations of these quantities for QTA were within about $\pm 2 \%$ of those of REF. Without any cruise-ship emissions (CLN), the correlation between haze index and wind speed was far less $(\mathrm{R}=0.38)$ because the existing particles and gases were around background concentrations. Thus, any transport by wind in/out of Glacier Bay replaced air with air of similar chemical composition.

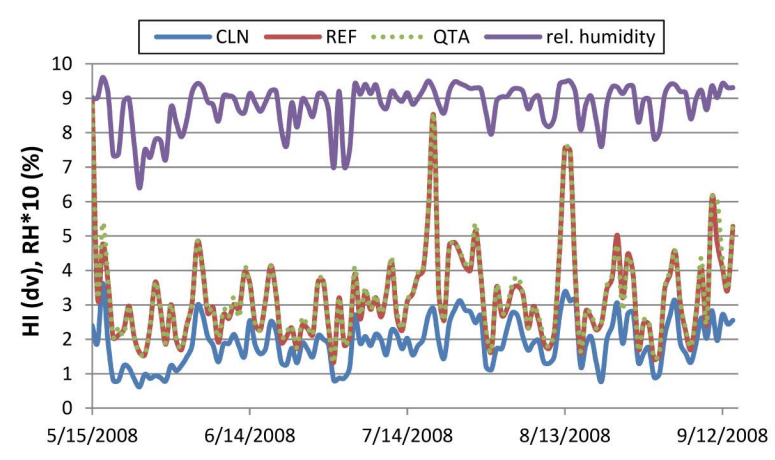

(a)

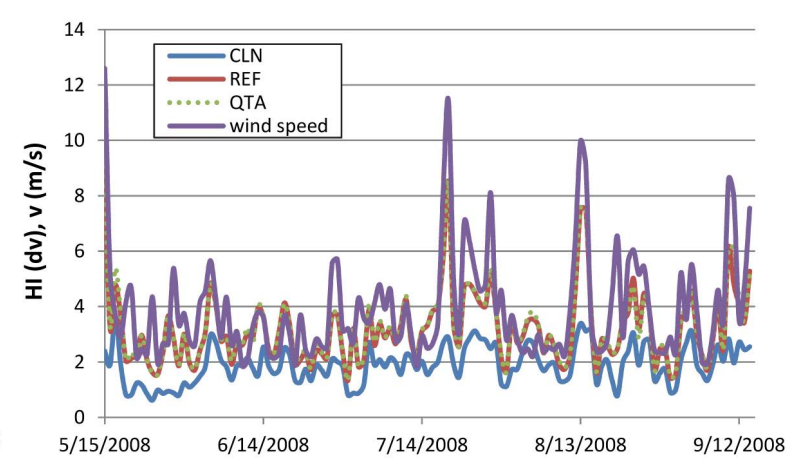

(b)

Figure 7. Temporal evolution of bay-wide daily mean haze index illustrating the relation to (a) relative humidity, and (b) to wind speed. 


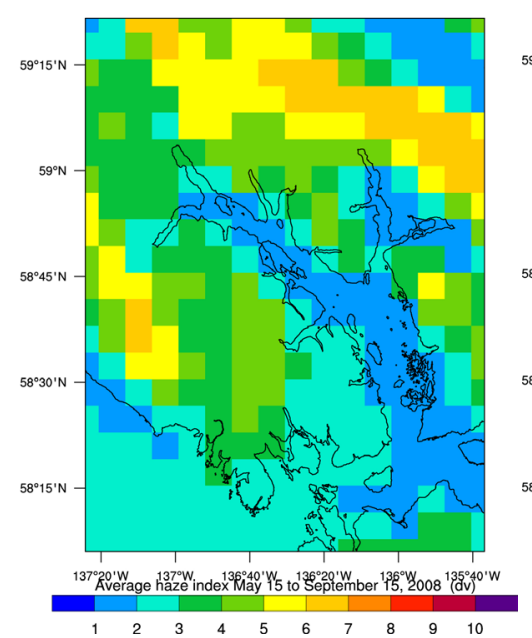

(a)

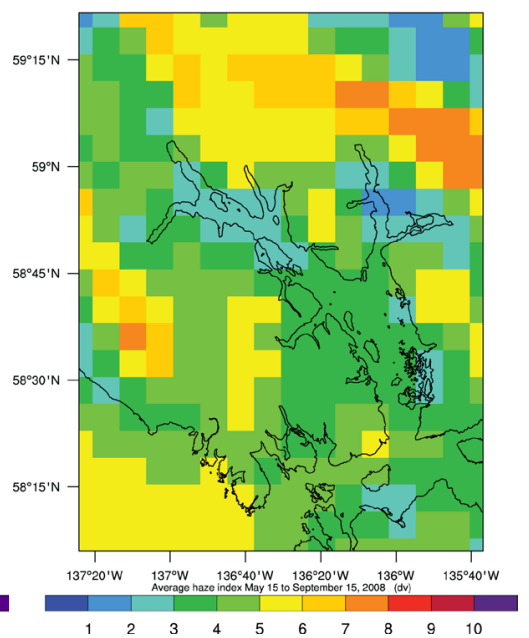

(b)

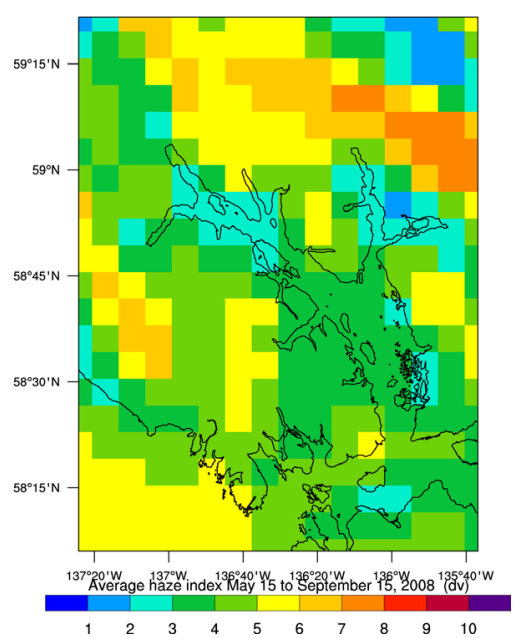

(c)

Figure 8. Zoom-in on tourist-season mean haze indices at ship height in Glacier Bay for (a) CLN, (b) REF, and (c) QTA. Low values indicate best visibility.

In summary, while humidity and natural $\mathrm{PM}_{2.5}$ determined visibility in Glacier Bay absent anthropogenic emissions (CLN), wind speed and the $\mathrm{PM}_{10}$ concentrations were the most influential in determining visibility in Glacier Bay in REF and QTA (Figure 7). For thermodynamical reasons, at the same high relative humidity, large particles are the first to swell. As compared to CLN, the increased number and size of PM in REF and QTA replaced $\mathrm{PM}_{2.5}$ by $\mathrm{PM}_{10}$ in reducing visibility. In contrast to CLN, in REF and QTA, transport of air in/out of Glacier Bay now exchanged air of different composition. Therefore, the correlation between $\mathrm{HI}$ and wind increased in REF and QTA as compared to CLN.

Comparison of the visibility on the seven days with identical emissions in REF and QTA showed bay-wide average increase of $0.2 \mathrm{dv}$ in QTA (Figure 4, Figure 7). This means that on these days, visibility was on average $1.1 \%$ less in QTA than in REF. The enhanced emissions of the previous days (e.g. Figure 4) and hence modified concentrations (Figure 5) caused this degradation of visibility (Figure 7).

In Glacier Bay at ship height, mean concentrations of $\mathrm{PM}_{10}$ and $\mathrm{PM}_{2.5}$ were $2 \%$, and $3 \%$ higher in QTA, while those of $\mathrm{NO}_{2}$ were $5 \%$ lower in QTA than in REF on the seven days of domain-wide identical emissions. Concentrations of $\mathrm{O}_{3}$, PAN or VOC differed less than $1 \%$ on average over these seven days $\left(\mathrm{NO}_{2}\right.$ decreased while PAN, VOC, and $\mathrm{O}_{3}$ remained nearly constant). This means that the additional primary aerosols from emissions on previous days together with enhanced secondary aerosol formation degraded the visibility on those seven days with domain-wide identical emissions in REF and QTA.

We compared HI-values of days without cruise-ship visits in Glacier Bay in REF with those of CLN. Pollutants remaining from emissions in Glacier Bay on previous days and/or advection increased the $\mathrm{HI}$ by about $46 \%$ on these days. On average, concentrations on days without emissions in Glacier Bay in REF were by a factor of 12.2, 2.5, 1.4 2.2, 1.2, and 1.4 higher for $\mathrm{PM}_{10}, \mathrm{PM}_{2.5}, \mathrm{SO}_{2}, \mathrm{NO}_{2}, \mathrm{PAN}$, and VOC than in CLN, while $\mathrm{O}_{3}$ concentrations remained about the same. These findings suggest that cruise-ship emissions from previous days, along with formation of secondary $\mathrm{PM}$ from precursors $\left(\mathrm{NO}, \mathrm{SO}_{2}, \mathrm{NH}_{3}\right)$ caused the on average $1.5 \mathrm{dv}$ higher haze index in REF on cruise-free days as compared to CLN (Figure 4, Figure 7).

Together these findings indicate that while ship emissions contributed to degraded visibility in REF and QTA in Glacier Bay, meteorology primarily governed visibility. Increases in ship-visit quotas as assumed here would have relatively small impacts on visibility and air quality as compared to the situation with the current quota.

\section{Discussion and Conclusions}

The National Park Service has the mandate to manage and preserve natural resources for current and future generations, while also allowing visitation and use. In Glacier Bay, about $97 \%$ of the visitors to the park arrive on board of cruise ships because the park does not have roads connecting it to Canada or other parts of Alaska. Since the associated emissions can affect air quality and visitor experience, an important consideration is the 
extent to which ships degrade these resources in the park. It is also important to understand how potential increases in allowable ship entries, as demand for glacier viewing keeps increasing, may affect air quality.

Since no long-term atmospheric visibility and air-quality monitoring existed in Glacier Bay, we performed a simulation study using WRF/Chem, and used the 2008 cruise-ship activity [12] as baseline (REF) to consider the impacts of potential increases, wherein two ships were allowed to enter the park each day between May 15 and September 15 (QTA). Another simulation without any cruise-ship emissions (CLN) served to understand the impacts of current activities as compared to conditions driven solely by biogenic processes and atmospheric conditions.

Simulations demonstrated that emissions of cruise-ships had little impact on daily means of bay-averaged meteorological conditions. Differences in bay-wide daily near-surface means ranged around current measurement accuracy (about $\pm 0.1^{\circ} \mathrm{C}$ for $2 \mathrm{~m}$ air temperature, $\pm 1 \%$ for $2 \mathrm{~m}$ relative humidity, $\pm 1 \mathrm{~cm}$ for $10 \mathrm{~m}$ wind speed, \pm 1 Pa for surface pressure) during most of the season. This finding suggests that effects from cruise-ship visits on weather conditions within the bay would be hard to detect with current instrument techniques.

We also found that ozone concentrations were independent of the cruise-emissions and remained so even when cruise-ship entry quotas increased. Whereas on days when no cruise ships visited Glacier Bay in REF $\mathrm{PM}_{10}, \mathrm{PM}_{2.5}, \mathrm{SO}_{2}, \mathrm{NO}_{2}, \mathrm{PAN}$, and VOC concentrations were all higher (by factors ranging from 1.2 - 12.2) compared to $\mathrm{CLN}, \mathrm{O}_{3}$ concentrations remained about the same. From these results, we infer that vegetation impacts from changes in $\mathrm{O}_{3}$ concentrations are not a likely result of cruise ship entries into Glacier Bay.

Overall, however, there was a general nonlinear relationship between increased emissions from increased cruise-ship traffic and concentration changes. The altered emissions meant different chemical regimes and shifts in the reaction paths thereby again modifying the concentrations as well as deposition fluxes.

Differences in chemical paths due to cruise-ship emissions explain why on some days in REF higher $\mathrm{SO}_{2}$ concentrations occurred compared to QTA despite more cruise-ship entries in QTA. This non-intuitive finding resulted from the competition of $\mathrm{SO}_{2}$ and $\mathrm{NO}_{\mathrm{x}}$ for $\mathrm{NH}_{3}$ in aerosol formation, and $\mathrm{NO}_{\mathrm{x}}$ being involved in many other chemical reaction paths. Based on these findings, we infer that the chemical regimes of wet, dry and occult deposition in Glacier Bay depend on the combination, and amount of emissions as well as on ambient temperature and relative humidity conditions.

We also conclude that due to the nonlinear relationship between emissions, concentrations and impacts, and because gas-to-particle growth in the accumulation mode shifts $\mathrm{PM}_{2.5}$ to $\mathrm{PM}_{10}$ and shrinking of particles shifts $\mathrm{PM}_{10}$ to $\mathrm{PM}_{2.5}$ that emissions can both degrade and increase visibility, depending upon ambient meteorological and chemical conditions. While we found that in most cases, degraded air-quality results of emissions, due to the otherwise pristine atmosphere, it is important to consider carefully the complexity of atmospheric chemistry and anthropogenic emissions in Glacier Bay.

CLN simulations demonstrated that relative humidity was the primary driver causing low visibility in Glacier Bay $(\mathrm{R}=0.68)$. In contrast to CLN, haze indices in REF (and QTA) were highly correlated $(\mathrm{R}>0.7$ ) with the particulate matter concentrations. This means that particularly in this humid area of frequent inversions [11] emissions notably contributed to reduced visibility. However, while the relative decrease in visibility from cruise-ship emissions was high (REF or QTA compared to CLN), visibility at ship height was better than the 2018 target set by the US EPA for pristine areas.

Although our findings indicate the meteorology largely dictates visibility, we also conclude that cruise-ship emissions contributed to degrade visibility and may affect which days have best/worst visibility. In contrast to CLN, in REF and QTA, haze indices correlated highly with the particulate matter concentrations $(\mathrm{R}>0.7)$ and wind speed $(\mathrm{R}=0.83)$. The correlation between HI and relative humidity in REF or QTA decreased as compared to CLN. Together these findings mean that in this region of frequent inversions [11], ventilation or the lack thereof govern visibility when emissions occur in the ABL in Glacier Bay. In conclusion, degraded visibility shifts towards a combined pollutant-meteorology issue when cruise-ship emissions occur and/or increase in Glacier Bay particularly in the upper fjord area where inversions are more likely to occur.

The study showed that in a fjord like Glacier Bay, primary and secondary pollutants form cruise-ship emissions still affect the chemical composition and regime of the ABL a day later. The additional primary aerosols from previous days together with enhanced secondary aerosol formation led to about $0.2 \mathrm{dv}$ degraded visibility in QTA on days with identical emissions in REF and QTA.

Days without cruise-ship visits in Glacier Bay in REF had about 46\% higher haze indices than the same days in CLN. These findings also suggest that the cruise-ship emissions in Glacier Bay dominated the degradation in 
visibility in the bay, but the emissions from previous days and in the upwind (generally from the Pacific Ocean) contributed to the degradation.

Combining results from this and related studies, we infer that increases in cruise-ship quota will only marginally affect air quality and visibility in Glacier Bay as compared to the current quota. Most poor visibility days namely were due to ambient conditions (relative humidity, calm wind) although with increases in ship entries there will be higher likelihood that visitor experience may be affected when haze forms from ship emissions during inversions and on humid days. While calm wind hardly affected visibility in CLN, wind speed gained similar importance as relative humidity when cruise-ship emissions (REF, QTA) occurred in Glacier Bay.

Finally, we highlight that total emissions varied dramatically among cruise-ships due to differences in size, passenger volume, engine type and power, etc. Thus, a future consideration for cruise-ship entries may be to consider the ship-specific attributes for mitigating emissions per visitor. Such an initiative would be consistent with similar on-going efforts in the West Norwegian Fjords World Heritage Site (termed the Green Fjord 2020 initiative) that seeks elevated sustainability of individual operations of cruise ships to minimize impacts to air and water quality while still maintaining levels of visitation.

\section{Acknowledgements}

We thank Gerhard Kramm, and the anonymous reviewers for fruitful discussions, the Geophysical Institute's Research Computing Support for access to HPC and providing CPU time and storage, and the National Park Service (Cooperative Ecosystem Studies Unit; contract P11AT30883/P11AC90465) for financial support.

\section{References}

[1] Eijgelaar, E., Thaper, C. and Peeters, P. (2010) Antarctic Cruise Tourism: The Paradoxes of Ambassadorship, "Last Chance Tourism” and Greenhouse Gas Emissions. Journal of Sustainable Tourism, 18, 337-354. http://dx.doi.org/10.1080/09669581003653534

[2] National Park Service (2006) Management Policies 2006. Management of National Park Service Programs, Washington DC.

[3] Eyring, V., Köhler, H.W., van Aardenne, J. and Lauer, A. (2005) Emissions from International Shipping: 1. The Last 50 Years. Journal of Geophysical Research, 110, Article ID: D17305. http://dx.doi.org/10.1029/2004JD005620

[4] Corbett, J.J., Lack, D.A., Winebrake, J.J., et al. (2010) Arctic Shipping Emissions Inventories and Future Scenarios. Atmospheric Chemistry and Physics, 10, 9689-9704. http://dx.doi.org/10.5194/acp-10-9689-2010

[5] Capaldo, K., Corbett, J.J., Kasibhatla, P., Fischbeck, P. and Pandis, S.N. (1999) Effects of Ship Emissions on Sulphur Cycling and Radiative Climate Forcing over the Ocean. Nature, 400, 743-746. http://dx.doi.org/10.1038/23438

[6] Derwent, R.G., Stevenson, D.S., Doherty, R.M., et al. (2009) The Contribution from Shipping Emissions to Air Quality and Acid Deposition in Europe. AMBIO: A Journal of the Human Environment, 34, 54-59. http://dx.doi.org/10.1579/0044-7447-34.1.54

[7] Dalsøren, S.B., Eide, M.S., Myhre, G., et al. (2010) Impacts of the Large Increase in International Ship Traffic 20002007 on Tropospheric Ozone and Methane. Environmental Science and Technology, 44, 2482-2489. http://dx.doi.org/10.1021/es902628e

[8] Hindley, A. and Font, X. (2014) Ethics and Influences in Tourist Perceptions of Climate Change. Current Issues in Tourism, 1-17. http://dx.doi.org/10.1080/13683500.2014.946477

[9] Law, K.S. and Stohl, A. (2007) Arctic Air Pollution: Origins and Impacts. Science, 315, 1537-1540. http://dx.doi.org/10.1126/science.1137695

[10] Liu, X., Gu, J., Li, Y., et al. (2013) Increase of Aerosol Scattering by Hygroscopic Growth: Observation, Modeling, and Implications on Atmospheric Visibility. Atmospheric Research, 132-133, 91-101. http://dx.doi.org/10.1016/j.atmosres.2013.04.007

[11] Pirhalla, M.A., Gende, S. and Mölders, N. (2014) Fate of Particulate Matter from Cruise-Ship Emissions in Glacier Bay during the 2008 Tourist Season. Journal of Environmental Protection, 4, 1235-1254. http://dx.doi.org/10.4236/jep.2014.512118

[12] Mölders, N., Gende, S. and Pirhalla, M.A. (2013) Assessment of Cruise Ship Activity Influences on Emissions, Air Quality, and Visibility in Glacier Bay National Park. Atmospheric Pollution Research, 4, 435-445. http://dx.doi.org/10.5094/apr.2013.050

[13] Platnick, S. and Twomey, S. (1994) Determining the Susceptibility of Cloud Albedo to Changes in Droplet Concentra- 
tion with the Advanced Very High Resolution Radiometer. Journal of Applied Meteorology, 33, 334-347. http://dx.doi.org/10.1175/1520-0450(1994)033<0334:DTSOCA>2.0.CO;2

[14] Seinfeld, J.H. and Pandis, S.N. (1997) Atmospheric Chemistry and Physics, from Air Pollution to Climate Change. John Wiley \& Sons, New York, 1326 p.

[15] Menut, L., Tripathi, O., Colette, A., et al. (2013) Evaluation of Regional Climate Simulations for Air Quality Modelling Purposes. Climate Dynamics, 40, 2515-2533. http://dx.doi.org/10.1007/s00382-012-1345-9

[16] Shulski, M. and Wendler, G. (2007) The Climate of Alaska. University of Alaska Press, Fairbanks, 216 p.

[17] National Park Service (2009) Glacier Bay National Park and Preserve Foundation Statement. http://www.nps.gov/glba/learn/management/upload/GLBA_Foundation.pdf.

[18] Skamarock, W.C., Klemp, J.B., Dudhia, J., et al. (2008) A Description of the Advanced Research WRF Version 3. NCAR/TN, 125 p.

[19] Peckham, S.E., Fast, J., Schmitz, R., et al. (2011) WRF/Chem Version 3.3 User's Guide. 96 p.

[20] Mölders, N., Bruyère, C.L., Gende, S. and Pirhalla, M.A. (2014) Assessment of the 2006-2012 Climatological Fields and Mesoscale Features from Regional Downscaling of CESM Data by WRF-Chem over Southeast Alaska. Atmospheric and Climate Sciences, 4, 589-613. http://dx.doi.org/10.4236/acs.2014.44053

[21] Grell, G.A. and Dévényi, D. (2002) A Generalized Approach to Parameterizing Convection. Geophysical Research Letters, 29, 38-1-38-4. http://dx.doi.org/10.1029/2002GL015311

[22] Hong, S.-Y. and Lim, J.O.J. (2006) The WRF Single-Moment 6-Class Microphysics Scheme (WSM6). Journal of Korean Meteorological Society, 42, 129-151.

[23] Chou, M.-D. and Suarez, M.J. (1994) An Efficient Thermal Infrared Radiation Parameterization for Use in General Circulation Models. NASA Technical Memorandum 104606, Technical Report Series on Global Modeling and Data Assimilation, Volume 3, National Aeronautics and Space Administration, Greenbelt, 85 p.

[24] Mlawer, E.J., Taubman, S.J., Brown, P.D., Iacono, M.J. and Clough, S.A. (1997) Radiative Transfer for Inhomogeneous Atmospheres: RRTM, a Validated Correlated-K Model for the Long Wave. Journal of Geophysical Research, 102D, 16663-16682. http://dx.doi.org/10.1029/97JD00237

[25] Barnard, J., Fast, J., Paredes-Miranda, G., Arnott, W. and Laskin, A. (2010) Technical Note: Evaluation of the WRFChem “Aerosol Chemical to Aerosol Optical Properties” Module Using Data from the MILAGRO Campaign. Atmospheric Chemistry and Physics, 10, 7325-7340. http://dx.doi.org/10.5194/acp-10-7325-2010

[26] Janjić, Z.I. (2002) Nonsingular Implementation of the Mellor-Yamada Level 2.5 Scheme in the NCEP Meso Model. NCEP Office Note, $61 \mathrm{p}$.

[27] Chen, F. and Dudhia, J. (2000) Coupling an Advanced Land-Surface/Hydrology Model with the Penn State/NCAR MM5 Modeling System. Part I: Model Description and Implementation. Monthly Weather Review, 129, 569-585. http://dx.doi.org/10.1175/1520-0493(2001)129<0569:CAALSH>2.0.CO;2

[28] Stockwell, W.R., Middleton, P., Chang, J.S. and Tang, X. (1990) The Second-Generation Regional Acid Deposition Model Chemical Mechanism for Regional Air Quality Modeling. Journal of Geophysical Research, 95, 16343-16367. http://dx.doi.org/10.1029/JD095iD10p16343

[29] Madronich, S. (1987) Photodissociation in the Atmosphere, 1, Actinic Flux and the Effects of Ground Reflections and Clouds. Journal of Geophysical Research, 92, 9740-9752. http://dx.doi.org/10.1029/JD092iD08p09740

[30] Wesely, M.L. (1989) Parameterization of Surface Resistances to Gaseous Dry Deposition in Regional-Scale Numerical Models. Atmospheric Environment, 23, 1293-1304. http://dx.doi.org/10.1016/0004-6981(89)90153-4

[31] Mölders, N., Tran, H.N.Q., Quinn, P., et al. (2011) Assessment of WRF/Chem to Capture Sub-Arctic Boundary Layer Characteristics during Low Solar Irradiation Using Radiosonde, Sodar, and Station Data. Atmospheric Pollution Research, 2, 283-299. http://dx.doi.org/10.5094/APR.2011.035

[32] Ackermann, I.J., Hass, H., Memmesheimer, M., et al. (1998) Modal Aerosol Dynamics Model for Europe: Development and First Applications. Atmospheric Environment, 32, 2981-2299. http://dx.doi.org/10.1016/S1352-2310(98)00006-5

[33] Schell, B., Ackermann, I.J., Hass, H., Binkowski, F.S. and Ebel, A. (2001) Modeling the Formation of Secondary Organic Aerosol within a Comprehensive Air Quality Model System. Journal of Geophysical Research, 106, 2827528293. http://dx.doi.org/10.1029/2001JD000384

[34] Simpson, D., Guenther, A., Hewitt, C.N. and Steinbrecher, R. (1995) Biogenic Emissions in Europe 1. Estimates and Uncertainties. Journal of Geophysical Research, 100D, 22875-22890. http://dx.doi.org/10.1029/95JD02368

[35] Guenther, A. (1997) Seasonal and Spatial Variations in Natural Volatile Organic Compound Emissions. Ecological Applications, 7, 34-45. http://dx.doi.org/10.1890/1051-0761(1997)007[0034:SASVIN]2.0.CO;2 
[36] Petzold, A., Feldpausch, P., Fritzsche, L., et al. (2004) Particle Emissions from Ship Engines. Journal of Aerosol Science, 35, S1095-S1096.

[37] Mölders, N., Porter, S.E., Cahill, C.F. and Grell, G.A. (2010) Influence of Ship Emissions on Air Quality and Input of Contaminants in Southern Alaska National Parks and Wilderness Areas during the 2006 Tourist Season. Atmospheric Environment, 44, 1400-1413. http://dx.doi.org/10.1016/j.atmosenv.2010.02.003

[38] Department of Commerce (2000) NCEP FNL Operational Model Global Tropospheric Analyses, Continuing from July 1999. Research Data Archive at the National Center for Atmospheric Research, Computational and Information Systems Laboratory.

[39] Sisler, J.F. and Malm, W.C. (2000) Interpretation of Trends of $\mathrm{PM}_{2.5}$ and Reconstructed Visibility from the IMPROVE Network. Journal of the Air \& Waste Management Association, 50, 775-789. http://dx.doi.org/10.1080/10473289.2000.10464127

[40] Cotton, W.R. and Pielke, R.A. (2007) Human Impacts on Weather and Climate. 2nd Edition, Cambridge University Press, Cambridge. http://dx.doi.org/10.1017/CBO9780511808319

[41] Zhang, Y., Wen, X.Y. and Jang, C.J. (2010) Simulating Chemistry-Aerosol-Cloud-Radiation-Climate Feedbacks over the Continental US Using the Online-Coupled Weather Research Forecasting Model with Chemistry (WRF/Chem). Atmospheric Environment, 44, 3568-3582. http://dx.doi.org/10.1016/j.atmosenv.2010.05.056

[42] Grell, G.A., Freitas, S.R., Stuefer, M. and Fast, J.D. (2011) Inclusion of Biomass Burning in WRF-Chem: Impact on Wildfires on Weather Forecasts. Atmospheric Chemistry and Physics, 11, 5289-5303. http://dx.doi.org/10.5194/acp-11-5289-2011

[43] Zhang, B., Wang, Y. and Hao, J. (2015) Simulating Aerosol-Radiation-Cloud Feedbacks on Meteorology and Air Quality over Eastern China under Severe Haze Conditions in Winter. Atmospheric Chemistry and Physics, 15, 23872404. http://dx.doi.org/10.5194/acp-15-2387-2015

[44] Webb, K. and Gende, S.M. (2015) Activity Patterns and Speeds of Large Cruise Ships in Southeast Alaska. Coastal Management, 43, 67-83. http://dx.doi.org/10.1080/08920753.2014.989148

[45] ENVIRON (2002) Commercial Marine Emission Inventory Development. Final Report, 163 p.

[46] Kramm, G., Dlugi, R., Dollard, G.J., et al. (1995) On the Dry Deposition of Ozone and Reactive Nitrogen Compounds. Atmospheric Environment, 29, 3209-3231. http://dx.doi.org/10.1016/1352-2310(95)00218-N

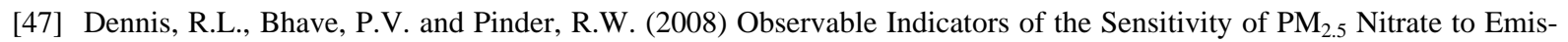
sion Reductions-Part II: Sensitivity to Errors in Total Ammonia and Total Nitrate of the CMAQ-Predicted NonLinear Effect of $\mathrm{SO}_{2}$ Emission Reductions. Atmospheric Environment, 42, 1287-1300. http://dx.doi.org/10.1016/j.atmosenv.2007.10.036

[48] Leelasakultum, K., Mölders, N., Tran, H.N.Q. and Grell, G.A. (2012) Potential Impacts of the Introduction of Low Sulfur Fuel on $\mathrm{PM}_{2.5}$-Concentrations at Breathing Level in a Subarctic City. Advances in Meteorology, 2012, 1-17. http://dx.doi.org/10.1155/212/427078

[49] Environmental Protection Agency (2007) Guidance on the Use of Models and Other Analyses for Demonstrating Attainment of Air Quality Goals for Ozone, $\mathrm{PM}_{2.5}$, and Regional Haze. EPA, Research Triangle Park, 262 p. 